\title{
Neuroendocrine regulation of gonadotropin secretion in seasonally breeding birds
}

\author{
Takayoshi Ubuka ${ }^{1,2 *}$, George E. Bentley ${ }^{3}$ and Kazuyoshi Tsutsui ${ }^{1}$ \\ ${ }^{1}$ Department of Biology, Center for Medical Life Science, Waseda University, Shinjuku, Tokyo, Japan \\ 2 Department of Biology, College of Liberal Arts and Sciences, Tokyo Medical and Dental University, Ichikawa, Japan \\ ${ }^{3}$ Department of Integrative Biology and Helen Wills Neuroscience Institute, University of California at Berkeley, Berkeley, CA, USA
}

Edited by:

Gregoy Y. Bedecarrats, University of

Guelph, Canada

Reviewed by:

Cynthia L. Bethea, Oregon Health

and Science University, USA

Gustavo M. Somoza, Instituto de

Investigaciones

Biotecnologicas-Instituto

Tecnologico de Chascomus

(IIB-INTECH), Argentina

T. Rajendra Kumar, University of

Kansas Medical Center, USA

Gábor B. Makara, Institute of

Experimental Medicine, Hungarian

Academy of Sciences, Hungary

Horst-Werner Korf, Goethe

University Frankfurt am Main,

Germany

\section{*Correspondence:}

Takayoshi Ubuka, Laboratory of Integrative Brain Sciences,

Department of Biology, Waseda University, 2-2 Wakamatsu-cho,

Shinjuku, Tokyo 162-8480, Japan. e-mail: t.ubuka@aoni.waseda.jp
Seasonally breeding birds detect environmental signals, such as light, temperature, food availability, and presence of mates to time reproduction. Hypothalamic neurons integrate external and internal signals, and regulate reproduction by releasing neurohormones to the pituitary gland. The pituitary gland synthesizes and releases gonadotropins which in turn act on the gonads to stimulate gametogenesis and sex steroid secretion. Accordingly, how gonadotropin secretion is controlled by the hypothalamus is key to our understanding of the mechanisms of seasonal reproduction. A hypothalamic neuropeptide, gonadotropin-releasing hormone $(\mathrm{GnRH})$, activates reproduction by stimulating gonadotropin synthesis and release. Another hypothalamic neuropeptide, gonadotropin-inhibitory hormone $(\mathrm{Gn} / \mathrm{H})$, inhibits gonadotropin synthesis and release directly by acting on the pituitary gland or indirectly by decreasing the activity of GnRH neurons. Therefore, the next step to understand seasonal reproduction is to investigate how the activities of $\mathrm{GnRH}$ and $\mathrm{GnIH}$ neurons in the hypothalamus and their receptors in the pituitary gland are regulated by external and internal signals. It is possible that locallyproduced triiodothyronine resulting from the action of type 2 iodothyronine deiodinase on thyroxine stimulates the release of gonadotropins, perhaps by action on $\mathrm{GnRH}$ neurons. The function of $\mathrm{GnRH}$ neurons is also regulated by transcription of the $\mathrm{GnRH}$ gene. Melatonin, a nocturnal hormone, stimulates the synthesis and release of $\mathrm{GnlH}$ and $\mathrm{GnlH}$ may therefore regulate a daily rhythm of gonadotropin secretion. GnlH may also temporally suppress gonadotropin secretion when environmental conditions are unfavorable. Environmental and social milieus fluctuate seasonally in the wild. Accordingly, complex interactions of various neuronal and hormonal systems need to be considered if we are to understand the mechanisms underlying seasonal reproduction.

Keywords: seasonal reproduction, hypothalamus-pituitary-gonadal axis, gonadotropins, gonadotropin-releasing hormone, gonadotropin-inhibitory hormone, thyroid hormone, melatonin, stress

\section{INTRODUCTION}

Seasonal changes in reproductive physiology and behavior of birds are under hypothalamic control of pituitary gonadotropin (luteinizing hormone, LH; follicle-stimulating hormone, FSH) secretion. Gonadotropins secreted from the anterior pituitary gland stimulate gametogenesis (spermatogenesis, oogenesis) and sex steroid (androgens, estrogens, progestogens) synthesis in the gonad. Gonadal steroids induce the development of secondary sexual characteristics and facilitate reproductive behavior. A hypothalamic neuropeptide, gonadotropin-releasing hormone $(\mathrm{GnRH})$, activates reproduction by stimulating gonadotropin synthesis and release. Another hypothalamic neuropeptide, gonadotropin-inhibitory hormone $(\mathrm{GnIH})$, inhibits gonadotropin synthesis and release directly by acting on the pituitary gland or indirectly by decreasing the activity of GnRH neurons. This review attempts to understand how $\mathrm{GnRH}$ and GnIH neuronal systems can integrate external and internal environmental information and regulate gonadotropin secretion to time seasonal reproduction in birds (Figure 1).

\section{SEASONAL REPRODUCTION}

\section{ENVIRONMENTAL INFORMATION ACCORDING TO SEASON}

Birds time their breeding so that young are hatched when there is enough food for them to be raised (Lack, 1968). Seasonal breeding is thought to be regulated by two sets of environmental factors, "ultimate" and "proximate" factors (Baker, 1938). The most important ultimate factor is thought to be the availability of an adequate food supply for the mother during the final stages of ovarian development as well as for the hatchlings. Other ultimate factors may include nesting conditions, predation pressure, and climate factors. These ultimate factors are not necessarily the ones used to trigger and regulate the initial secretion of reproductive hormones, because it is necessary to anticipate the hatching date and to begin preparations for breeding ahead of the time when the offspring must be produced (Follett, 1984).

In birds living in mid and high latitudes the annual change in day length controls the timing of breeding; photoperiod is thus the predominant proximate factor for birds living in such regions (Follett, 1984). Other environmental factors can accelerate or 


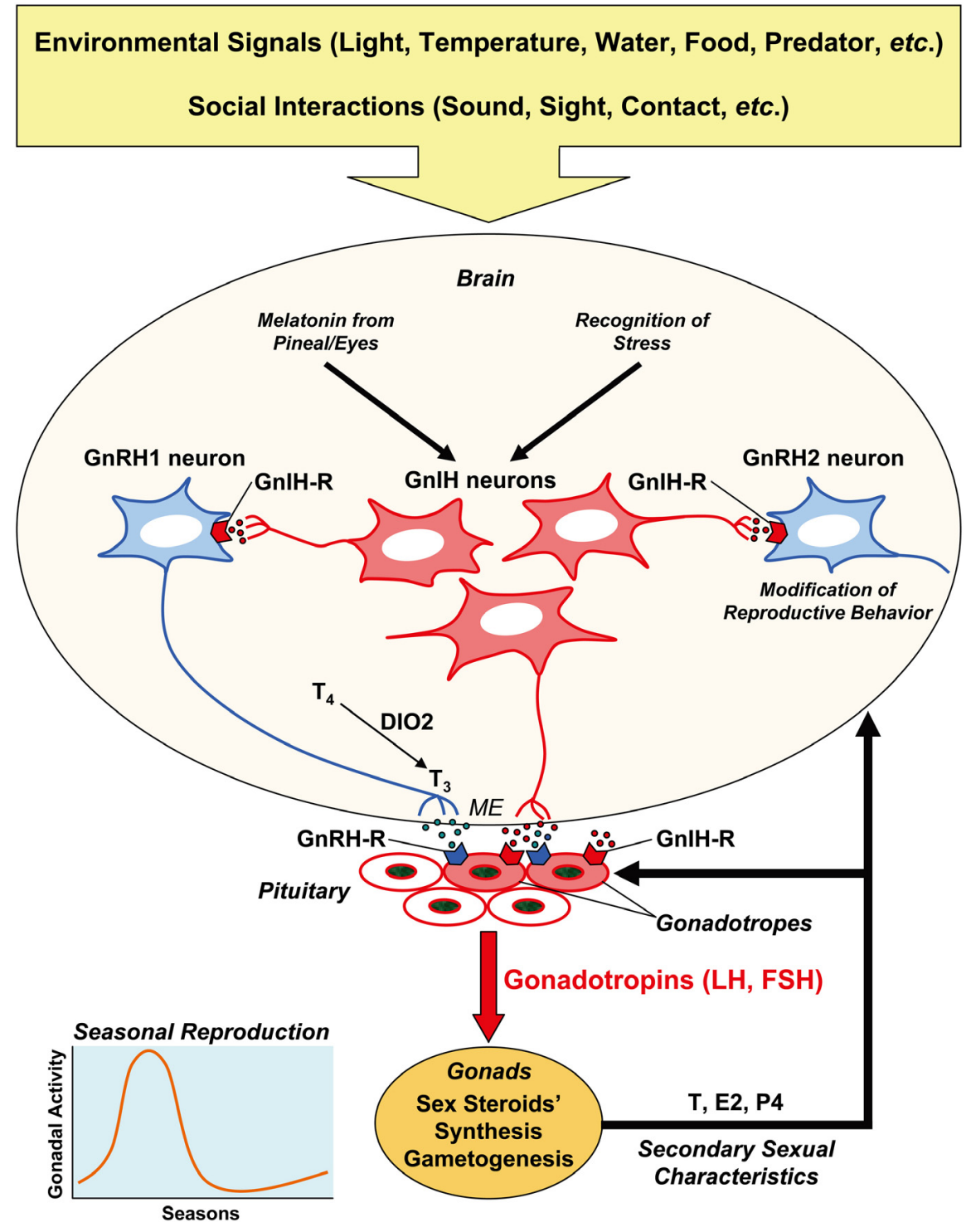

FIGURE 1 | Schematic model of the mechanism of seasonal reproduction in birds. Seasonal breeding birds detect environmental signals, such as light, temperature, water, and food availability, predator pressure, etc. to time reproduction. Their reproductive activity is also shaped by social interactions with the conspecifics, in terms of sound, sight, contact, etc. Hypothalamic neurons in the bran integrate external and internal signals, and regulate reproduction by releasing neurohormones at the median eminence (ME) to regulate the pituitary hormone secretion. The anterior pituitary gland synthesizes and releases gonadotropins (LH, FSH), and gonadotropins act on the gonads to stimulate gametogenesis and sex steroid secretion. Sex steroids induce secondary sexual characteristics of the organism. A hypothalamic neuropeptide, $\mathrm{GnRH1}$, activates reproduction by stimulating gonadotropin synthesis and release via its receptor $(\mathrm{GnRH}-\mathrm{R})$ expressed on the gonadotropes. Another hypothalamic neuropeptide, GnlH, may inhibit gonadotropin synthesis and release directly by acting on the pituitary or indirectly by decreasing the activity of $\mathrm{GnRH} 1$ neurons via its receptor $(\mathrm{GnlH}-\mathrm{R})$ expressed on the gonadotropes and $\mathrm{GnRH}$ neurons. $\mathrm{GnRH} 2$ neurons may stimulate reproductive behavior, and $\mathrm{GnIH}$ may inhibit reproductive behavior by inhibiting $\mathrm{GnRH} 2$ neurons. $\mathrm{GnRH}$ and $\mathrm{GnIH}$ neurons in the hypothalamus and their receptors in the pituitary are also regulated by internal signals, such as testosterone (T), estradiol (E2), and progesterone (P4). It is hypothesized that locally produced triiodothyronine $\left(T_{3}\right)$ from thyroxine $\left(T_{4}\right)$ by the action of type 2 iodothyronine deiodinase (DIO2) at the mediobasal hypothalamus stimulates the release of $\mathrm{GnRH}$. The function of $\mathrm{GnRH} 1$ neurons is also regulated by transcription of the $\mathrm{GnRH}$ gene. Because melatonin, a nocturnal hormone, stimulates the synthesis and release of $\mathrm{GnIH}$ in birds, $\mathrm{GnIH}$ may regulate daily rhythm of gonadotropin secretion. GnlH may also temporally suppress gonadotropin secretion when environmental or social condition is unfavorable. retard photoperiodically-induced gonadal growth (Farner and Follett, 1979). These include rainfall (Leopold et al., 1976), ambient temperature (Perrins, 1973), and the presence of males for stimulating ovarian development (Marshall, 1936; Hinde, 1965;
Cheng, 1979; Bentley and Ball, 2000). On the other hand, it is thought that photoperiod is not the proximate factor for many tropical and desert species (Marshall, 1970). The proximate factors used to time breeding in tropical birds remain largely 
unknown although correlative analyses suggest rainfall, territory, nest site availability, nest materials, and food supply are involved (Immelmann, 1971; Zann et al., 1995). The reproductive axis of tropical birds may remain in a state of "readiness to breed," and full functionality may be triggered by the relevant proximate cues (Perfito et al., 2006).

\section{PHOTOPERIOD}

The majority of temperate-zone passeriformes undergo dynamic seasonal changes in their reproductive activities. Gonadal development occurs in spring in response to increasing day length ("photostimulation"). However, the gonads are maintained in a functional condition only for a short period, and they spontaneously regress after extended exposure to long day lengths ("absolute photorefractoriness"). After becoming photorefractory, exposure to short day lengths is required for many passeriforme birds to regain "photosensitivity" and thus allow for photostimulation again (Wingfield and Farner, 1980; Dawson et al., 2001). Note that absolute photorefractoriness occurs when day lengths are still increasing.

A condition similar to absolute photorefractoriness is "relative photorefractoriness." Even if relative photorefractoriness has been induced and the gonads have regressed, a subsequent substantial increase in day length will initiate reproductive maturation without the need for a short day length "sensitization" in some birds, such as Japanese quail (Robinson and Follett, 1982). If quail experience day lengths of over $11.5 \mathrm{~h}$, rapid gonadal development occurs. After about 3 months and when day length decreases below $14.5 \mathrm{~h}$ of light per day (in the wild) complete gonadal regression occurs (Nicholls et al., 1988). However, if the day length is subsequently artificially increased further, a full return to reproductive maturity occurs. If quail are maintained on any constant long day length, no form of photorefractoriness will be elicited unless they experience a decrease in day length, for example, from $23 \mathrm{~h}$ of light per day to $16 \mathrm{~h}$ (Nicholls et al., 1988).

Song sparrows and house sparrows show characteristics of both absolute and relative photorefractoriness (Dawson et al., 2001). Song sparrows (Wingfield, 1983) and house sparrows (Dawson, 1998a) eventually become photorefractory during exposure to long photoperiods, but the timing can vary widely among individuals. If, in a laboratory environment, the length of the long day is decreased slightly, gonadal regression occurs sooner and is more synchronized among individuals. Song sparrows can show renewed gonadal maturation without the exposure to short photoperiods to "break" photorefractoriness and induce photosensitivity that is required in absolutely photorefractory species (Wingfield, 1993).

\section{PHOTORECEPTOR}

It is thought that light can affect the behavior and physiology of birds via three different pathways: the eyes, the pineal, and the deep brain (Underwood et al., 2001). The avian eye is not only a functional photoreceptor, but also contains a circadian clock(s) and produces a circadian rhythm of melatonin secretion (Binkley et al., 1980; Hamm and Menaker, 1980). The principal cells within the pineal of most non-mammalian vertebrates have characteristics of a photosensory cell, including the presence of an outer segment composed of stacked disks containing photopigments (Collin and Oksche, 1981). The avian pineal organ is photosensitive and it is also the locus of a circadian pacemaker (Takahashi and Menaker, 1984; Okano and Fukada, 2001). The location of the extrapineal-extraretinal photoreceptors mediating circadian entrainment in birds has not been established. In a study using opsin antibodies, cerebrospinal fluid-contacting cells were labeled in the septal and the tuberal areas in the ring dove (Silver et al., 1988), and lateral septum in the pigeon (Wada et al., 2000). Light and confocal microscopy revealed interactions of GnRH-immunoreactive (-ir) and opsin-ir materials in the preoptic area (POA) and in the median eminence, suggesting a direct communication between these putative deep brain photoreceptors and GnRH neurons (Saldanha et al., 2001). Recently, Nakane et al. (2010) have reported that Opsin 5 (OPN5; also known as GPR136, Neuropsin, PGR12, and TMEM13)-ir neurons in the paraventricular organ (PVO) contact the cerebrospinal fluid and extend their fibers to the external zone of the median eminence adjacent to the pars tuberalis of the pituitary gland, which may translate photoperiodic information into neuroendocrine responses (Nakane et al., 2010).

\section{MEASUREMENT OF DAYLENGTH}

The circadian system is involved in birds' measurement of day length. In a classic experiment, white-crowned sparrows held on short day lengths [ $8 \mathrm{~h}$ light $(8 \mathrm{~L}): 16 \mathrm{~h}$ dark (16D)] were placed in continuous darkness. When birds were exposed to a single $8 \mathrm{~h}$ photophase (light period), an increase in LH occurred only if the photophase coincided with a time period $12-20 \mathrm{~h}$ after the subjective dawn (Follett et al., 1974). There are two possible models of how circadian rhythms might be involved in photoperiodic time measurement in birds (Goldman, 2001). The "external coincidence model" assumes that the organism possesses a circadian rhythm of "photosensitivity." If coincidence between this rhythm and light occurs under long days, it induces gonadotropin secretion. The "internal coincidence model" assumes that the induction occurs when coincidence is established between two separate circadian oscillators (dawn and dusk oscillators). As a consequence of using a circadian clock for photoperiodic time measurement, light is not required throughout the day to induce gonadal growth, but pulses of light simulating dawn and dusk can cause induction if one of the pulses coincides with the phase of photosensitivity (Follett, 1973). If $15 \mathrm{~min}$ pulses of light were given at different times in the night to quail housed on a light:dark cycle of $6 \mathrm{~L}: 18 \mathrm{D}$, induction occurs only if the pulses are within 12 to $16 \mathrm{~h}$ after dawn (Follett and Sharp, 1969).

Light intensity can also modify the reproductive responses of birds under the same photoperiod (Bissonnette, 1931; Bartholomew, 1949). Bentley et al. (1998) showed that photosensitive starlings transferred from short days to long days of different light intensities underwent graded reproductive responses according to the light intensities they experienced. The growth in their testes size and the development of photorefractoriness were similar to those seen in starlings exposed to different photoperiods. These data contradict the external coincidence model in that light falling in the photoinducible phase should cause a long day response. However, this discrepancy might be explained 
by the possibility that low light intensities only weakly entrain the circadian oscillations of the photoinducible phase, so that light is experienced in only part of the photoinducible phase (Bentley et al., 1998).

\section{BIOLOGICAL CLOCK AND CALENDAR}

The circadian system of birds is composed of several interacting sites, including the pineal organ, the suprachiasmatic nucleus (SCN) of the hypothalamus, and eyes. Each of these sites may contain a circadian clock (Underwood et al., 2001). However, significant variation exists among birds in the relative roles that the pineal, the SCN, and the eyes play within the circadian system and influence circadian activity patterns. For example, in the house sparrow circadian pacemakers in the pineal play the predominant role, whereas in the pigeon circadian pacemakers in both the pineal and eyes play a significant role. In Japanese quail, ocular pacemakers play the predominant role. There has been controversy on the precise location of the avian homologs of the mammalian SCN. The medial hypothalamic nucleus (MHN, also termed the medial SCN) and the lateral hypothalamic retinorecipient nucleus (LHRN, also termed the visual SCN) are the possible homologs of the mammalian SCN (Cassone and Moore, 1987; Norgren and Silver, 1989, 1990; Shimizu et al., 1994).

A self-sustaining circadian oscillation in the cells of clock structures is generated by a transcription-translation feedback loop of clock genes, the presence of which appears to be a conserved property from fruit flies to humans. Clock and Period homologs (qClock, qPer2, and qPer3) were cloned in the Japanese quail. qPer2 and qPer3 showed robust circadian oscillations in the eye and in the pineal gland, although qClock mRNA was expressed throughout the day. qPer2 mRNA was induced by light, whereas qClock or qPer3 were not (Yoshimura et al., 2000). These clock genes were expressed in the MHN, but not in the LHRN in quail (Yoshimura et al., 2001). On the other hand, Per2 mRNA is expressed both in the MHN and in the LHRN with rhythmic expression patterns in the house sparrow (Abraham et al., 2002). Clock genes such as Per, Cry, Clock, Bmal, E4bp4 are all expressed and differentially oscillate in quail and chicken pineal gland (Doi et al., 2001; Okano et al., 2001; Yamamoto et al., 2001; Fukada and Okano, 2002; Yasuo et al., 2003). The avian pineal gland seems to possess a functional circadian oscillator composed of a transcription/translation-based autoregulatory feedback loop as in the mammalian SCN (Fukada and Okano, 2002). Thus, multiple oscillators are present in birds, and they are somehow coordinated to convey circadian rhythmicity.

Annual seasonal activities of birds, such as reproduction, molt, and migration can persist for many cycles with a period deviating from 12 months under constant conditions. These cycles have been named "circannual rhythms" (Gwinner, 2003), although many of them deviate significantly from a 12 month period. These cycles have been experimentally demonstrated for at least 20 species of birds under specific lighting conditions (Gwinner, 1986; Gwinner and Dittami, 1990; Guyomarc'h and Guyomarc'h, 1995). In European starlings, a cycle of photosensitive and photorefractory phases continues in constant photoperiods close to $12 \mathrm{~h}$ (Gwinner, 1996; Dawson, 1997). Under photoperiods longer than $12 \mathrm{~h}$ starlings remain in the photorefractory state, whereas under shorter photoperiods they remain in the photosensitive state (Gwinner, 1996). Castrated starlings exposed to 12L:12D did not exhibit cyclic rhythms of this type (Dawson and McNaughton, 1993). Accordingly, the reproductive cycle that was observed for intact birds under this specific constant photoperiod (12L:12D) might be generated as a result of complex interactions within the hypothalamus-pituitary-gonadal (HPG) axis, rather than as a result of a circannual "calendar" in the brain (Ubuka and Bentley, 2011).

\section{MELATONIN}

The pineal glands of all vertebrates show daily rhythms in the activity of the enzymes in the indolamine-synthesizing pathway that produces 5-methoxy-N-acetyltryptamine (melatonin). Plasma melatonin concentration is always higher at night in both diurnal and nocturnal animals. Melatonin is synthesized from serotonin by the action of $\mathrm{N}$-acetyltransferase to $\mathrm{N}$-acetylserotonin, and by hydroxyindole-O-methyltransferase (HIOMT) to melatonin. Rhythms of melatonin synthesis and release from the pineal gland have been shown in pigeons, house sparrows, quail, and chicken. Circadian rhythms in melatonin secretion from the cultured pineal gland can persist in constant condition and they can be entrained by $24 \mathrm{~h}$ light-dark cycles (Murakami et al., 1994; Barrett and Takahashi, 1997; Brandstätter et al., 2000, 2001). Significantly, the eyes can contribute up to $30 \%$ of plasma melatonin in pigeons and Japanese quail (Underwood et al., 1984; Oshima et al., 1989). The eyes of Japanese quail show a rhythm in melatonin content (high at night, low in the day) that can be entrained by light directed exclusively to the eyes (Underwood et al., 1990). Circadian pacemakers in the pineal and in the eyes are thought to communicate with the hypothalamic pacemakers via the rhythmic synthesis and release of melatonin (Chabot and Menaker, 1992; Underwood et al., 2001).

Three melatonin receptor subtypes, Mella, Mel1b, and Mel1c are identified in birds. These are G-protein-coupled receptors (GPCRs) (Reppert et al., 1995). Mella and Mellc receptors are present in the LHRN (visual SCN) in the chicken brain (Reppert et al., 1995). Contrary to the melatonin rhythm, which is higher in the scotophase (dark period), [125I]-iodomelatonin binding in the brain is higher during the photophase and lower during the scotophase in chicken (Yuan and Pang, 1992), quail (Yuan and Pang, 1990), and pigeon (Yuan and Pang, 1991). Sex differences and the effect of photoperiod on [125I]-iodomelatonin binding were also observed in the avian brain. Density of melatonin binding sites was higher in males than in females in some telencephalic nuclei (e.g., HVC and Area X) of songbirds (zebra finch, house sparrow), and in the visual pathways and the POA in quail (Aste et al., 2001). Quail belonging to the short day (8L:16D) group expressed a significantly higher melatonin receptor density in the optic tectum and nucleus triangularis, while the long day (16L:8D) animals had a higher density of receptors in the hyperstriatum and nucleus preopticus dorsalis (Panzica et al., 1994). Recently, Bentley et al. (2012) have shown season- and contextdependent sex differences in melatonin receptor density in Area X of European starlings (Bentley et al., 2012).

Photoperiodic mammals rely on the annual cycle of changes in nocturnal secretion of melatonin to drive their reproductive 
responses (Bronson, 1990). In contrast, a dogma exists that birds do not use seasonal changes in melatonin secretion to time their reproductive effort and a role for melatonin in birds has remained enigmatic (Bentley, 2001). The effects of pinealectomy $(\mathrm{Px})$, bilateral orbital enucleation (Ex), and Px plus Ex on seasonal regulation of reproduction were tested in tree sparrows, a highly photoperiodic species (Wilson, 1991). Although there was an accelerating effect of Ex on the changes in their testicular size, $\mathrm{Px}, \mathrm{Ex}$, and Px plus Ex birds revealed photostimulation, photorefractoriness, and recovery of photosensitivity in the same time course as in intact birds. The effects of artificial extension of the duration of circulating melatonin on reproductive status were tested using Japanese quail by exogenous melatonin injection (Juss et al., 1993). Male quail reared under non-stimulatory short days (8L:16D) were switched to $12 \mathrm{~L}: 12 \mathrm{D}$ and given daily melatonin injections at dusk $(10 \mu \mathrm{g} 2 \mathrm{~h}$ before dusk and $10 \mu \mathrm{g}$ at dusk) or at dawn ( $10 \mu \mathrm{g} 2 \mathrm{~h}$ before dawn and $10 \mu \mathrm{g}$ at dawn) for 3 weeks. Contrary to the prediction, melatonin injection resulted in significant stimulation of $\mathrm{LH}$ concentration and testicular size. Despite the accepted dogma, there is evidence that melatonin is involved in the regulation of seasonal reproductive processes. Male Japanese quail reared under non-stimulatory short days (8L:16D) were used to test the effect of anti-melatonin antibody (anti-MEL) administration on the reproductive status (Ohta et al., 1989). Intravenous injection of anti-MEL just before lights-off for 3 days significantly increased testosterone ( $\mathrm{T}$ ) concentration and testicular size after 2 weeks even if the quail were kept under the same non-stimulatory photoperiod (8L:16D). There are also reports showing inhibitory effects of melatonin on seasonal recrudescence in quail (Guyomarc'h et al., 2001) and on LH secretion in chicken (Rozenboim et al., 2002). In a more recent study on wild great tits, melatonin administration significantly delayed the onset of egg-laying in spring (Greives et al., 2012).

\section{TEMPERATURE}

Japanese quail do not show a complete decrease in levels of circulating LH concentrations or complete involution of the testes following transfer from long to short days without decreasing the temperature in the laboratory. Wada et al. (1990) have experimentally demonstrated that low ambient temperature together with the change of the photoperiod from long to short days was required to reduce circulating $\mathrm{LH}$ concentration to a nonbreeding level at which the gonad and the accessory sex organs regressed completely. Photoperiodic changes from long to short days under moderate temperature resulted in a decrease in circulating $\mathrm{LH}$ to the basal breeding level that could maintain activity of the gonads and the accessory sex organs. These results suggest that ambient temperature can influence the timing of termination of reproductive activity in Japanese quail (Wada et al., 1990; Tsuyoshi and Wada, 1992).

Kobayashi et al. (2004) investigated the effect of short day length and low temperature on pituitary mRNA levels of LH $\beta$ and common $\alpha$ subunit in male Japanese quail under natural and laboratory conditions. When birds were kept in outdoor cages under natural conditions at Waseda University in Tokyo $\left[35^{\circ} 42^{\prime} \mathrm{N}, 139^{\circ} 43^{\prime} \mathrm{E}\right.$; monthly mean atmospheric temperature: $27.4^{\circ} \mathrm{C}$ in August (highest), $6.1^{\circ} \mathrm{C}$ in January (lowest)], both $\mathrm{LH} \beta$ and common $\alpha$ mRNA levels decreased rapidly from August to September, and after a period of low levels from October through January, they began to increase in February and continued to increase until July. Plasma LH concentration followed similar changes in quail housed in outdoor cages in Tokyo (Wada et al., 1992). When birds were kept in the laboratory and transferred from long day length (16L:8D) at $20^{\circ} \mathrm{C}$ (LD20) to short day length (8L:16D) at $20^{\circ} \mathrm{C}(\mathrm{SD} 20)$ or $9^{\circ} \mathrm{C}$ (SD9) for 14 days, although pituitary LH $\beta$ and common $\alpha$ mRNA levels, plasma LH concentration, and testicular weight decreased significantly in SD9, their decrease was moderate in SD20. However, low temperatures under long days did not induce any significant change in these parameters (Kobayashi et al., 2004).

Wingfield et al. (2003) have investigated the effects of temperature on photoperiodically induced reproductive development and regression in mountain white-crowned sparrows (Z. l. oriantha). Captive populations of mountain white-crowned sparrows showed robust gonadal development following transfer to longs days (15L:9D), but low temperature $\left(5^{\circ} \mathrm{C}\right)$ slowed down photoperiodically induced gonadal growth and subsequent regression, in both males and females. High temperature of $30^{\circ} \mathrm{C}$ tended to accelerate gonadal development and regression whereas gonadal development was intermediate in a group exposed to $20^{\circ} \mathrm{C}$. Prior exposure to these temperature regimes while on short days (9L:15D) had no effect. However, there was no effect of temperature on photoperiodically induced rises in $\mathrm{LH}$ in either sex despite marked effects on gonadal growth (Wingfield et al., 2003). Dawson (2005) has investigated the effect of temperature on photoperiodically regulated gonadal maturation, regression and molt in starlings. Common starlings were kept in two indoor aviaries, in which photoperiod tracked natural changes, but temperature was held at either $20^{\circ} \mathrm{C}$ or $5^{\circ} \mathrm{C}$ (year 1 ), or at $18^{\circ} \mathrm{C}$ or $8^{\circ} \mathrm{C}$ (year 2). Although temperature had no effect on the rate or timing of testicular maturation, testicular regression occurred significantly earlier at the higher temperatures. Post-nuptial molt also started significantly earlier in both males and females (Dawson, 2005). These studies demonstrate that temperature has significant effects on reproduction also in songbirds.

\section{SOCIAL INTERACTION}

Considering the social nature of reproduction, it is not surprising that social interactions have dramatic effects on reproductive physiology and behavior in vertebrates (Hinde, 1965; Lehrman, 1965; Crews and Silver, 1985; Searcy, 1992; Wingfield et al., 1994; Maruska and Fernald, 2011). Male courtship behaviors can greatly enhance the development of reproductive physiology and behaviors of female birds. Bentley et al. (2000b) investigated the effects of conspecific and heterospecific song on reproductive development in domesticated (canaries) and wild songbirds (song sparrows). Although conspecific and heterospecific songs were equally effective in enhancing ovarian development, conspecific song induced oviposition earlier and at a greater frequency than in heterospecific and no song groups, with the fewest eggs being laid in the no song group (Bentley et al., 2000b). 


\section{SEASONAL CHANGE IN GONADOTROPIN SECRETION}

Seasonal changes in reproductive activities are generally correlated with gonadotropin secretion. The primary effect of long day lengths on stimulating gonadotropin secretion has been shown in many birds, such as quail (Follett, 1976), white-crowned sparrow (Wingfield and Farner, 1980), tree sparrow (Wilson and Follett, 1974), canary (Nicholls, 1974), duck (Balthazart et al., 1977), and starlings (Dawson and Goldsmith, 1983). If male quail are transferred from short day lengths to long day lengths, the levels of gonadotropins rise substantially during the first week of photostimulation. Testicular growth and steroidogenesis begin and maturity is reached in about 5 weeks (Follett and Robinson, 1980). Gonadal steroids also affect gonadotropin secretion by negative feedback (King et al., 1989a; Dunn and Sharp, 1999). Female quail also grow their ovaries as a result of increased gonadotropin secretion induced by long day lengths. Gonadotropin levels become basal after transferring quail from long days to short days (Gibson et al., 1975). On the contrary, in most of the temperate-zone Passeriform birds, which undergo spontaneous photorefractoriness after exposure to long days, gonadotropin secretion is diminished and gonadal collapse occurs after a species-specific number of long days (Follett, 1984).

Seasonal change in gonadotropin secretion continues in the absence of the gonads. Castrated or intact quail show an identical time-course in LH and FSH secretion under natural photoperiods over 2 consecutive years, the difference being that in summer the gonadotropin levels in castrated birds are higher, as a result of lack of negative feedback from gonadal steroids (Follett, 1984). A similar annual cycle of LH secretion was observed in the plasma of intact and castrated white-crowned sparrows (Mattocks et al., 1976). It is also thought that gonads are not required for photorefractoriness to develop, because castrated white-crowned sparrows (Wingfield et al., 1980), canaries (Storey et al., 1980), and starlings (Dawson and Goldsmith, 1984) show a spontaneous fall in gonadotropin level under long days. Castration of photorefractory canaries does not cause enhanced LH secretion, but when photosensitivity is regained under short days there is an immediate rise in plasma LH (Nicholls and Storey, 1976).

\section{ROLE OF GnRH AND ITS RECEPTOR}

Reproductive activities of vertebrates are primarily regulated by $\mathrm{GnRH}$ in the hypothalamus. This decapeptide was originally isolated from mammals (Matsuo et al., 1971; Burgus et al., 1972) and subsequently from chicken (King and Millar, 1982a,b; Miyamoto et al., 1982). The molecular structure of the originally isolated mammalian GnRH (mGnRH-I) is pEHWSYGLRPG-NH $\mathrm{N}_{2}$. Chicken GnRH-I (cGnRH-I; pEHWSYGLQPG-NH ${ }_{2}$ ) differs by one amino acid from mGnRH-I, in that glutamine is substituted for arginine at position 8 . Specific genes encoding the same cGnRH-I peptide were identified by cDNA cloning in Galliformes (chicken, quail, turkey) (Dunn et al., 1993; Kang et al., 2006), Anseriformes (goose, duck) (Huang et al., 2008), Columbiformes (dove) (Mantei et al., 2008), and Passeriformes (zebra finch, European starlings) (Stevenson et al., 2009; Ubuka and Bentley, 2009; Ubuka et al., 2009a). Existence of cGnRH-I peptide was also suggested in songbirds by high-performance liquid chromatography (HPLC) and cross-reactivity with various $\mathrm{GnRH}$ antisera (Sherwood et al., 1988). There is a second form of GnRH, which is called chicken GnRH-II (cGnRH-II). cGnRH-II was first found in chicken and subsequently in mammals (Miyamoto et al., 1984; King et al., 1989b; Morgan and Millar, 2004; Millar, 2005) and eventually in all vertebrate groups (Roch et al., 2011). The

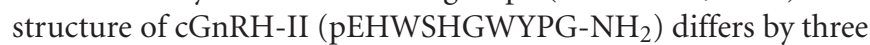
amino acids from mGnRH-I or cGnRH-I at positions 5, 7, and 8. Most of the phylogenetic analyses support the existence of three GnRH clades in gnathostomes, named GnRH1, GnRH2, and GnRH3 (Tostivint, 2011). Depending on this classification, cGnRH-I and cGnRH-II belongs to GnRH1 and GnRH2 groups, respectively. Accordingly, we refer to cGnRH-I and cGnRH-II as GnRH1 and GnRH2, respectively, in this review (Figure 1).

Specific antibodies against avian $\mathrm{GnRH}$ peptides (GnRH1 and GnRH2) were made, and the histological localization of GnRHs was studied in chicken and quail (Mikami et al., 1988; van Gils et al., 1993). In mammals, the GnRH1 neurons originate at the olfactory placode and migrate to preoptic-septal nuclei during embryonic development (Schwanzel-Fukuda and Pfaff, 1989; Wray et al., 1989). The migration of GnRH1 neurons from the olfactory placode to the forebrain along the olfactory nerve was also observed in chickens (Norgren and Lehman, 1991; Akutsu et al., 1992; Yamamoto et al., 1996). In adult birds, GnRH1-ir cell bodies are found in a fairly wide area covering the POA to the thalamic region. On the contrary, magnocellular GnRH2-ir cell bodies were found in the area dorsomedial to the nervus oculomotorius in the midbrain. Fibers immunoreactive for GnRH1 or GnRH2 were widely distributed in the telencephalon, diencephalon, and mesencephalon (midbrain). In sharp contrast to the existence of abundant GnRH1-ir fibers in the external layer of the median eminence, GnRH2-ir fibers were absent or less prominent in this area, suggesting that the major GnRH controlling pituitary function is GnRH1 (Mikami et al., 1988; van Gils et al., 1993). Clerens et al. (2003) have isolated GnRH2-ir substances in the quail median eminence by high performance liquid chromatography (HPLC) and identified it by radioimmunoassay (RIA). The GnRH2-ir substances isolated by immunoaffinity chromatography, present in the quail median eminence extract, were also subjected to mass spectrometry. The immunoreactive peptide had a mass of $1235.56 \mathrm{Da}$, which is the same as synthetic GnRH2. In addition, MS/MS fragmentation generated an amino acid sequence corresponding to the sequence of GnRH2 (Clerens et al., 2003). This study unequivocally demonstrates the existence of $\mathrm{GnRH} 2$ in the median eminence of quail, although it may not be the major GnRH controlling pituitary function.

Specific RIAs for chicken LH (Follett et al., 1972), turkey LH (Burke et al., 1979), and chicken FSH (Scanes et al., 1977; Sakai and Ishii, 1980) have been developed and used to measure the effect of GnRH on gonadotropin release. The action of GnRH1 on LH release from chicken anterior pituitary cells was first shown in vitro (Millar and King, 1983). Subsequently, the effect of GnRH1 on LH and FSH release was shown both in vivo and in vitro in quail (Hattori et al., 1985). The activity of GnRH1 on $\mathrm{LH}$ release was more marked than that on FSH release both in vivo and in vitro (Hattori et al., 1985). The effect of GnRH2 on LH and FSH release was also shown in vivo and in vitro (Hattori et al., 1986). The activity of GnRH2 on LH and FSH release was 
almost equal to that of GnRH1. The action of GnRH2 on LH release was again more marked than on FSH release both in vivo and in vitro. No synergism was observed between GnRH1 and GnRH2 on LH or FSH release in vitro (Hattori et al., 1986), suggesting that these effects may be pharmacological acting on the same receptor.

The physiological roles of GnRH1 and GnRH2 on LH release were investigated in chickens (Sharp et al., 1990). The amount of GnRH1 in the median eminence was higher in laying than in out-of-lay hens, as measured by RIA. GnRH2 was not detected in the median eminence. The amount of GnRH1 in the hypothalamus increased in cockerels at the onset of puberty, but the amount of GnRH2 did not change. Active immunization of laying hens against GnRH1 but not against GnRH2 resulted in complete regression of the reproductive system. Accordingly, it was concluded that gonadotropin secretion in chickens is more likely to be controlled by GnRH1 (Sharp et al., 1990). On the other hand, GnRH2 may be involved in the control of sexual behaviors in various animals (Millar, 2003; Okubo and Nagahama, 2008). It was shown that $\mathrm{GnRH} 2$, but not $\mathrm{GnRH} 1$, administered to the brain increased copulation solicitation display, a female courtship behavior, in female white-crowned sparrows (Maney et al., 1997) (Figure 1).

Three GnRH receptor subtypes (type I, II, III) have been identified with distinct distributions and functions in vertebrates (Millar et al., 2004). These receptor subtypes belong to the GPCR superfamily. Two receptor subtypes were identified in chickens: type I (GnRH-R-I; Sun et al., 2001a,b) and type III (GnRH-R-III; Shimizu and Bédécarrats, 2006), according to the classification by Millar et al. (2004). GnRH-R-I is widely expressed, and GnRH2 has a higher binding affinity to this receptor and is more potent in stimulating accumulation of inositol trisphosphate, a secondary messenger molecule that can induce gonadotropin release, than GnRH1 (Sun et al., 2001a,b). Inositol trisphosphate accumulation in response to GnRH2 binding to GnRH-R-III was also more marked than in response to $\mathrm{GnRH} 1$. Because fully processed GnRH-R-III mRNA was exclusively expressed in the pituitary, and its mRNA level was positively correlated with reproductive states in both sexes, it is likely that GnRH-R-III plays a role in the regulation of gonadotropin secretion by pituitary gonadotropes (Shimizu and Bédécarrats, 2006). Despite the implication here that GnRH2 is more effective in regulation of gonadotrope function, the current opinion is that GnRH1, and not GnRH2, is the dominant regulator of gonadotropin release (Figure 1).

\section{REGULATION OF GnRH AND GnRH-R BY PHOTOPERIOD}

RIA and immunocytochemistry (ICC) using GnRH antisera have demonstrated cyclic changes in GnRH in songbirds in response to changing photoperiod. RIA revealed that hypothalamic GnRH content did not increase significantly during the first 6 weeks of photostimulation in female starlings in a laboratory environment. However, by 12 weeks after the onset of photostimulation, as birds became photorefractory, $\mathrm{GnRH}$ had decreased to levels significantly lower than those before photostimulation (Dawson et al., 1985). ICC with quantitative image analyses for both GnRH and its precursor, proGnRH-GAP, was performed during photoperiodically-induced reproductive cycle in male starlings (Parry et al., 1997). The size of cells immunoreactive for GnRH and proGnRH-GAP increased during gonadal maturation. A reduction in the number of cells immunoreactive for GnRH and the size of cells immunoreactive for both GnRH and proGnRH-GAP occurred during gonadal regression, though immunoreactivity for GnRH and proGnRHGAP in the median eminence remained high. Immunoreactivity for GnRH and proGnRH-GAP was reduced significantly after gonadal regression. These observations suggest that photorefractoriness is promoted by a reduction in pro-GnRH-GAP and GnRH synthesis (Parry et al., 1997). Changes in GnRH1 in the POA and mediobasal hypothalamus $(\mathrm{MBH})$ including the median eminence were measured in starlings during the recovery of photosensitivity under short days, and following photostimulation at various times during the recovery of photosensitivity (Dawson and Goldsmith, 1997). During exposure of long day photorefractory starlings to short days for 10 days, there was a significant increase in GnRH1 in the POA but not in the $\mathrm{MBH}$. Photostimulation after 20 short days caused an immediate increase in GnRH1 in the POA, a delayed increase in the $\mathrm{MBH}$, but no increase in plasma LH. Photostimulation after 30 short days caused an immediate increase in GnRH1 in the POA and the $\mathrm{MBH}$ and in plasma LH. These results show that the recovery of photosensitivity is gradual and the first measurable change occurs in the POA, consistent with photosensitivity being due to renewed GnRH1 synthesis (Dawson and Goldsmith, 1997). Recently, the complete sequence of GnRH1 precursor mRNA was identified in Passerine birds, European starlings (Stevenson et al., 2009; Ubuka et al., 2009a) and zebra finch (Stevenson et al., 2009; Ubuka and Bentley, 2009). The expression of GnRH1 precursor mRNA was found to be regulated as a function of age and reproductive condition in zebra finch (Ubuka and Bentley, 2009). In starlings, there was regulation of $\mathrm{GnRH} 1$ precursor mRNA expression as a function of season in birds exposed to natural photoperiod (Ubuka et al., 2009a) and in response to artificial changes in photoperiod (Stevenson et al., 2009). Photostimulation of chickens and turkeys also increased GnRH1 precursor mRNA expression (Dunn and Sharp, 1999; Kang et al., 2006).

\section{BY THYROID HORMONE}

It has been known for many decades that thyroid hormones can affect reproductive function, but the effects of thyroidectomy on seasonal breeding were often contradictory (Dawson et al., 2001). Gonadal regression caused by photorefractoriness is normally prevented by thyroidectomy, but in some studies, photorefractoriness appears to have been accelerated (Dawson and Thapliyal, 2001). Treatment with one of the thyroid hormones, thyroxine $\left(\mathrm{T}_{4}\right)$, can mimic the effects of long photoperiods (Follett and Nicholls, 1988; Goldsmith and Nicholls, 1992; Wilson and Reinert, 1995). Reinert and Wilson (1996) argue in tree sparrows that the increase in plasma $\mathrm{T}_{4}$ concentrations following photostimulation (Sharp and Klandorf, 1981; Dawson, 1984) serves to program the subsequent gonadal cycle and molt. However, when Bentley et al. (1997) maintained $\mathrm{T}_{4}$ concentrations at subphysiological levels by treating thyroidectomized starlings held on long days with appropriate amounts of $\mathrm{T}_{4}$, these birds became 
photorefractory and molted. This result suggests that $\mathrm{T}_{4}$ simply has to be present for the appropriate responses to photoperiod to occur.

The site(s) of action of thyroid hormones may lie within the central nervous system since in starlings and sparrows, prevention of photorefractoriness by thyroidectomy is associated with maintenance of high levels of GnRH1, typical of photosensitive birds (Dawson et al., 1985; Reinert and Wilson, 1996; Dawson, 1998b). In addition, thyroidectomy of photorefractory birds results in an increase in GnRH1 (Dawson et al., 1986). Central administration of thyroid hormones to thyroidectomized tree sparrows restores all of the photoperiodic responses, with the effects of $\mathrm{T}_{4}$ being more potent than triiodothyronine, $\mathrm{T}_{3}$ (Wilson and Reinert, 2000). Chronic thyroidectomy appears to render starlings "photoperiodically blind," because the GnRH response to an increase or a decrease in photoperiod is greatly attenuated (Bentley et al., 2000a), although less chronically thyroidectomized starlings still exhibit a robust long day photoperiodic response (Bentley et al., 1997). In house sparrows, the effects of thyroidectomy are very different. Again thyroidectomized birds appear to be photoperiodically blind; testicular size and GnRH1 are the same whether birds are on long or short photoperiods (Dawson, 1998b). However, although GnRH1 remains high, which is typical of photosensitive birds, testicular size remains minimal, which is typical of photorefractory birds. Accordingly, thyroid hormone may have different effects on GnRH1 synthesis and release, which may account for the apparently contradictory results on the effects of thyroidectomy on reproductive processes.

Recent molecular analyses suggest that local thyroid hormone activation in the hypothalamus may play a critical role in the regulation of seasonal reproduction in birds (Nakao et al., 2008b). If the light exposure occurs around 11-16 h after dawn (photoinducible phase), then the first detectable change in gonadotropin secretion begins around $22 \mathrm{~h}$ after dawn in Japanese quail (Follett and Sharp, 1969), and a wave of gonadotropin secretion occurs over the next few days (Follett et al., 1977; Nicholls et al., 1983). Meddle and Follett (1997) examined the effect of the first long day on expression of a transcription factor, Fos, in the basal tuberal hypothalamus, a brain area that includes GnRH1 neuronal terminals. Transfer of short day (6L:18D) quail to long days induced Fos-ir in neuronal cells in the infundibular nucleus and glial cells in the median eminence by $18 \mathrm{~h}$ of the first long day. This activation of specific brain areas was followed by the first rise in $\mathrm{LH} 20 \mathrm{~h}$ after dawn (Meddle and Follett, 1997). Fos-ir in the infundibular nucleus and LH release were also stimulated by subcutaneous $\mathrm{N}$-methyl-D-aspartate administration in the white-crowned sparrow (Meddle et al., 1999). Yoshimura et al. (2003) hypothesized that important molecular events would be triggered in the $\mathrm{MBH}$ when light was given to quail during the photoinducible phase. Acute induction of type 2 iodothyronine deiodinase (DIO2) mRNA expression was observed in the ependymal cells of the $\mathrm{MBH}$ and in the infundibular nucleus by long-day treatments. DIO2 is an enzyme that catalyzes the conversion of $T_{4}$ to $T_{3}$, whereas type 3 iodothyronine deiodinase (DIO3) catalyzes the conversion of $\mathrm{T}_{4}$ and $\mathrm{T}_{3}$ to their inactive forms. Interestingly, the expression of DIO3 was down-regulated under long day conditions when DIO2 was up-regulated (Yasuo et al., 2005). Central administration of DIO2 inhibitor, iopanoic acid, reduced testicular growth of quail that were transferred from short to long day conditions (Yoshimura et al., 2003). $\mathrm{T}_{3}$ implantation to the $\mathrm{MBH}$ caused testicular growth and reduced encasement of nerve terminals by glial processes in the median eminence of quail (Yamamura et al., 2006). The glial processes do not physically occupy and block space in between axon terminals and capillaries of the portal system in the median eminence of photostimulated white-crowned sparrows, but they do in photorefractory birds (Bern et al., 1966; Mikami et al., 1970). Because GnRH nerve terminals are also in closer proximity to the basal lamina of the median eminence in long day quail (Yamamura et al., 2004), Yamamura et al. (2006) hypothesized a role for $\mathrm{T}_{3}$ in the regulation of photoperiodic GnRH secretion via neuro-glial plasticity in the median eminence.

In a more recent study, functional genomic analysis was performed using a chicken high-density oligonucleotide microarray during photoinduction in quail (Nakao et al., 2008a). The microarray detected two waves of gene expression in the $\mathrm{MBH}$. Interestingly, thyrotropin $\beta$ subunit (TSH $\beta$ ) mRNA expression peaked around $14 \mathrm{~h}$ after dawn, and up-regulation of DIO2 and down-regulation of DIO3 occurred around 18-19 h after dawn of the first long day. Spatio-temporal expression analyses of the genes revealed that the first wave events occurred in the pars tuberalis of the pituitary gland, whereas the second wave events occurred in the ependymal cells in the ventral walls of the third ventricle in the $\mathrm{MBH}$. Glycoprotein $\alpha$ mRNA, which codes for the common subunit for TSH, LH, and FSH, was cyclically expressed in the pars tuberalis. TSH receptor was observed in the in the ependymal cells in the ventral walls of the third ventricle in the $\mathrm{MBH}$, where the second wave genes were expressed, and the binding of [125I]-TSH was further observed. Intracerebroventricular administration of TSH induced the expression of DIO2, whereas anti-TSH $\beta$ antibody reduced DIO2 expression (Nakao et al., 2008a).

\section{BY MELATONIN}

What are the factors that induce TSH $\beta$ mRNA expression in pars tuberalis of short day quail by the first long day (Nakao et al., 2008a)? The removal of the inhibitory effect of melatonin on TSH $\beta$ mRNA expression may be a possible mechanism, because melatonin receptor (Mel1c) mRNA is expressed in the pars tuberalis in chicken (Kameda et al., 2002). Glycoprotein $\alpha$ is also expressed in pars tuberalis in chicken, and Px induces glycoprotein $\alpha$ subunit mRNA expression in the pars tuberalis (Kameda et al., 2002). Thus, local induction of thyroid hormones caused by changes in melatonin signaling might well be involved in at least the initial photoperiodic response. This may be one of the reasons why treatment with anti-melatonin just before lights-off for 3 days caused significant gonadal growth in quail kept in short day (8L:16D) condition (Ohta et al., 1989).

Although Px plus Ex treatment for 1 week eliminated melatonin concentration in the plasma, there was a substantial amount of melatonin-ir material remaining in the quail diencephalon, suggesting melatonin synthesis in the brain (Ubuka et al., 2005). Recently, a group of neurons that synthesize both dopamine and melatonin were identified in the premammillary nucleus of 
the turkey hypothalamus (Kang et al., 2007; El Halawani et al., 2009). These neurons express clock genes and a photoreceptor, melanopsin. Dopamine/melatonin neurons are activated when a light pulse is given during the photosensitive phase, associated with an up-regulation of GnRH1 mRNA expression. The expression of tryptophan hydroxylase 1 (serotonin synthesizing enzyme) mRNA level is low during the photophase and high during the scotophase, and tyrosine hydroxylase (rate limiting dopamine synthesizing enzyme) mRNA shows the opposite cycle. These hypothalamic dopamine/melatonin neurons may thus provide a novel role for melatonin in the regulation of seasonal reproductive cycles in birds (El Halawani et al., 2009). This finding may explain the lack of effect of Px and/or Ex on the avian reproductive system, because day length information could be encoded by the hypothalamic dopamine/melatonin neurons.

\section{BY SEX STEROIDS}

Effects of castration and estrogen administration to castrated birds on GnRH1 and GnRH-R-I mRNA expressions were studied in the cockerel (Sun et al., 2001a) (Figure 1). In juvenile cockerels, concentrations of GnRH1 mRNA in the POA increased after castration, and it was prevented by estrogen treatment. In the anterior pituitary gland, the concentration of GnRH-R-I mRNA increased after castration and it was reversed by estrogen treatment. On the other hand, in intact adult cockerels, estrogen treatment depressed plasma luteinizing hormone but did not affect concentrations of GnRH1 and GnRH-R-I mRNAs in the POA, basal hypothalamus, and anterior pituitary gland, suggesting that locally produced estrogen, by aromatization, may exert maximal suppression on GnRH1 and GnRH-R-I mRNAs (Sun et al., 2001a).

Effect of sex steroids on GnRH1 release from hypothalamic slices including medial basal hypothalamus and preoptic areas (MBH-POA) was studied in adult male Japanese quail (Li et al., 1994) (Figure 1). Short-term estradiol-17 $\beta$ (E2) exposure significantly potentiated norepinephrine (NE)-induced GnRH1 release. Neither T nor 5 alpha-dihydrotestosterone affected baseline or NE-stimulated GnRH1 release. On the contrary, pretreatment with E2 for $14 \mathrm{~h}$ in static culture before perifusion significantly reduced the NE-induced GnIH-I release. These data provide evidence for E2 modulation of GnRH1 release, which varies with exposure time (Li et al., 1994).

The mechanism whereby gonadal steroids modulate GnRHstimulated LH secretion by primary cultures of chicken pituitary cells was investigated (King et al., 1989a) (Figure 1). E2, T, and progesterone inhibited LH release stimulated by $\mathrm{GnRH}$, and the inhibitory effects required prolonged preincubation (24-48 h) with the steroids. E2 had no effect on binding of 125I-[His5,DTyr6] GnRH to a pituitary cell preparation. These findings suggest that the site of steroid modulation of $\mathrm{GnRH}$ action is distal to binding of GnRH to its receptor and that the inhibitory effects are exerted at intracellular sites (King et al., 1989a).

\section{BY SOCIAL INTERACTION}

Maney et al. (2007) played recordings of conspecific male song to laboratory-housed female white-throated sparrows and quantified the resulting rapid changes in LH as well as the induction of the immediate early gene Egr-1 in the GnRH neurons and $\mathrm{MBH}$. Hearing song for $42 \mathrm{~min}$ induced LH release and Egr-1 expression in the $\mathrm{MBH}$, but did not alter Egr-1 expression in GnRH neurons. The time course of LH release and the pattern of Egr-1 expression together suggest that song acts as a trigger to induce GnRH release. The Egr-1 response in the $\mathrm{MBH}$ was qualitatively distinguishable from the responses to either photostimulation or pharmacologically-induced LH release but seemed to involve overlapping neuronal populations (Maney et al., 2007).

\section{ROLE OF GnIH AND ITS RECEPTOR}

$\mathrm{GnIH}$ was first isolated in the brain of the Japanese quail, Coturnix japonica, while searching for a novel RFamide peptide in birds. RFamide peptides, which have an Arg-Phe- $\mathrm{NH}_{2}$ motif at their C-terminus, were first discovered in invertebrate species in the late 1970s. The first RFamide peptide, Phe-MetArg-Phe- $\mathrm{NH}_{2}$ (FMRFamide), was a cardioexcitatory molecule isolated from the ganglia of the venus clam Macrocallista nimbosa (Price and Greenberg, 1977). Since then, numerous RFamide peptides that act as neurotransmitters, neuromodulators, and peripheral hormones have been identified in various invertebrates, including cnidarians, nematodes, annelids, molluscs, and arthropods. Subsequent immunohistochemical studies in vertebrates suggested the presence of RFamide peptides in the central nervous system. Because some FMRFamide-ir neurons projected close to the pituitary gland, it was suggested that the immunoreactive substance may regulate pituitary function in vertebrates.

In 2000, Tsutsui et al. isolated a novel RFamide peptide from 500 Japanese quail brains by HPLC and a competitive enzymelinked immunosorbent assay using an antibody raised against the dipeptide Arg-Phe- $\mathrm{NH}_{2}$ (Tsutsui et al., 2000). The isolated peptide had a novel dodecapeptide structure, SIKPSAYLPLRFamide. Its C-terminus was identical to chicken LPLRFamide that was reported to be the first RFamide peptide isolated in vertebrates (Dockray et al., 1983), which may be a degraded fragment of the dodecapeptide. Because the isolated peptide was localized in the hypothalamo-hypophysial system, and shown to decrease gonadotropin release from cultured quail anterior pituitary glands, this RFamide peptide was named GnIH (Tsutsui et al., 2000) (Figure 1).

Following the isolation of GnIH from quail brain, a cDNA that encoded the GnIH precursor polypeptide was identified (Satake et al., 2001). The translated GnIH precursor consisted of 173 amino acid residues that encoded one $\mathrm{GnIH}$ and two GnIHrelated peptides ( $\mathrm{GnIH}-\mathrm{RP}-1$ and $\mathrm{GnIH}-\mathrm{RP}-2)$, all possessing an LPXRFamide ( $\mathrm{X}=\mathrm{L}$ or $\mathrm{Q}$ ) sequence at their C-termini. These peptide sequences were flanked by a glycine C-terminal amidation signal and a single basic amino acid on each end as an endoproteolytic site. GnIH-RP-2 was also identified as a mature peptide by mass spectrometry in quail (Satake et al., 2001). GnIH peptides were further isolated as mature peptides in European starlings (Ubuka et al., 2008a) and zebra finch (Tobari et al., 2010) within the class of birds (for reviews, see Tsutsui and Ukena, 2006; Tsutsui et al., 2006, 2010a,b, 2012; Ubuka et al., 2008b, 2012c; Tsutsui, 2009; Tsutsui and Ubuka, 2013). 
To elucidate the mode of action of GnIH in birds, Yin et al. (2005) identified the GnIH receptor (GnIH-R) in quail diencephalon and characterized its expression and binding activity (Yin et al., 2005). First, a cDNA encoding a putative GnIH-R was cloned using PCR primers designed from the sequence of GPR147, a specific receptor for RFamide related peptide that is the orthologous peptide family of GnIH (Hinuma et al., 2000; Ubuka et al., 2009b,c, 2012a). The crude membrane fraction of COS-7 cells transfected with the putative GnIH-R cDNA specifically bound GnIH and GnIH-RPs in a concentration-dependent manner, indicating that GPR147 is a GnIH-R candidate (Yin et al., 2005). GnIH-R also bound with high affinity to $\mathrm{GnIH}, \mathrm{GnIH}-$ RPs, and RFRPs, which have LPXRFamide (X $=\mathrm{L}$ or $\mathrm{Q})$ motif at their C-termini. In contrast, non-amidated $\mathrm{GnIH}$ failed to bind the receptor. Accordingly, the C-terminal LPXRFamide (X = L or Q) motif seems to be critical for its binding to GnIH-R. Although GnIH-R bound GnIH and GnIH-RPs with similar affinities in this study, further studies are required to investigate if $\mathrm{GnIH}$ and GnIH-RPs work additively or synergistically to achieve their effects on the cells that express GnIH-R.

Shimizu and Bédécarrats (2010) showed in the chicken pituitary gland that GnIH-R mRNA levels fluctuate in an opposite manner to GnRH-R-III, a pituitary specific form of GnRH receptor (Shimizu and Bédécarrats, 2006; Joseph et al., 2009), with higher level of GnIH-R mRNA and lower level of GnRH-R-III observed during inactive and active reproductive stages, respectively (Shimizu and Bédécarrats, 2010). They also demonstrated that the chicken GnIH-R signals by inhibiting cAMP production, most likely by coupling to $\mathrm{G}_{\alpha i}$. They also showed that this inhibition is sufficient to significantly reduce GnRH-induced cAMP responsive element (CRE) activation in a dose-dependent manner, and that the ratio of $\mathrm{GnRH} / \mathrm{GnIH}$ receptors was a significant factor. From these results they proposed that in avian species, sexual maturation is characterized by a change in $\mathrm{GnIH} / \mathrm{GnRH}$ receptor ratio, resulting in a switch in pituitary sensitivity from inhibitory, involving $\mathrm{GnIH}$, to stimulatory, involving GnRH. In turn, decreasing GnIH-R signaling, combined with increasing GnRH-R-III signaling, results in significant increases in CRE activation, possibly initiating gonadotropin synthesis (Shimizu and Bédécarrats, 2010). Son et al. (2012) intensively studied the intracellular cell signaling mechanism of GnIH using immortalized mouse gonadotrope cell line (L $\beta$ T2 cells). It was demonstrated that $\mathrm{GnIH}$ inhibits $\mathrm{GnRH}$ induced gonadotropin subunit gene transcriptions by inhibiting adenylate cyclase/cAMP/PKAdependent ERK pathway in L $\beta$ T2 cells (Son et al., 2012).

Although a dense population of $\mathrm{GnIH}$ neuronal cell bodies was only found in the paraventricular nucleus (PVN) of the hypothalamus, GnIH-ir neuronal fibers were widely distributed in the diencephalic and mesencephalic regions in birds (Ukena et al., 2003; Ubuka et al., 2008a, 2012b). Thus, it was hypothesized that GnIH may participate not only in the regulation of pituitary function, but also in behavioral and autonomic mechanisms in birds. Double-label immunocytochemistry showed $\mathrm{GnIH}$ axon terminals on GnRH1 and GnRH2 neurons in the starling brain, which is in agreement with an earlier study on house sparrows (Bentley et al., 2003; Ubuka et al., 2008a). In situ hybridization of starling GnIH-R mRNA combined with GnRH immunocytochemistry further showed the expression of GnIH-R mRNA in GnRH1 and GnRH2 neurons (Ubuka et al., 2008a) suggesting that GnIH modifies the activity of GnRH1 and GnRH2 neurons in the brain (Figure 1). GnRH2 enhances copulation solicitation in estrogenprimed female white-crowned sparrows exposed to the song of males (Maney et al., 1997). Because of the putative contact of GnIH neurons with GnRH2 neurons in white-crowned sparrows (Bentley et al., 2003), Bentley et al. (2006) investigated the effect of $\mathrm{GnIH}$ administration on copulation solicitation in females of this species. A centrally-administered physiological dose of $\mathrm{GnIH}$ inhibited copulation solicitation in estrogen-primed female white-crowned sparrows exposed to the song of males (Bentley et al., 2006) (Figure 1).

To identify the mechanism of GnIH neurons in the regulation of behavior, Ubuka et al. (2012b) investigated the effect of RNA interference (RNAi) of the GnIH gene on the behavior of white-crowned sparrows, a highly social songbird species. Administration of small interfering RNA against GnIH precursor mRNA into the third ventricle of male and female birds reduced resting time, spontaneous production of complex vocalizations, and stimulated brief agonistic vocalizations. GnIH RNAi further enhanced song production of short duration in male birds when they were challenged by playbacks of novel male songs. These behaviors resembled those of breeding birds during territorial defense. The overall results suggested that $\mathrm{GnIH}$ gene silencing induces arousal. In addition, the activities of male and female birds were negatively correlated with GnIH mRNA expression in the PVN. The density of GnIH neuronal fibers in the ventral tegmental area was decreased by GnIH RNAi treatment in female birds, and the number of $\mathrm{GnRH}$ neurons that received close appositions of GnIH neuronal fiber terminals was negatively correlated with the activity of male birds. In summary, GnIH may decrease arousal level resulting in the inhibition of specific motivated behavior, such as in reproductive contexts (Ubuka et al., 2012b, 2013) (Figure 1).

A dense population of $\mathrm{GnIH}$-ir fibers at the median eminence in quail (Tsutsui et al., 2000; Ukena et al., 2003; Ubuka et al., 2003) as well as in other birds (Bentley et al., 2003; Osugi et al., 2004; Ubuka et al., 2008a) suggested a direct action of GnIH in the regulation of pituitary function in birds (Figure 1). The fact that $\mathrm{GnIH}$ inhibits synthesis and/or release of gonadotropins from cultured quail and chicken anterior pituitary gland provides strong support for this function (Tsutsui et al., 2000; Ciccone et al., 2004; Maddineni et al., 2008). Peripheral administration of $\mathrm{GnIH}$ also inhibits gonadotropin synthesis and/or release in birds (Osugi et al., 2004; Ubuka et al., 2006). On the other hand, it was suggested that $\mathrm{GnIH}$ may not act directly on the pituitary in some birds, because there are relatively few or no GnIH-ir fibers in the median eminence of Rufous-winged sparrows (Small et al., 2007)—although the anterior pituitary gland of this species expresses mRNA for GnIH-R (McGuire, Deviche and Bentley, unpublished data).

Maddineni et al. (2008) characterized the expression of GnIH$\mathrm{R}$ mRNA and protein in the chicken pituitary gland. GnIH-Rir cells were identified in the chicken pituitary gland cephalic and caudal lobes and they were co-localized with LH $\beta$ mRNA or FSH $\beta$ mRNA containing cells. GnIH treatment significantly 
decreased LH release from anterior pituitary gland slices collected from sexually immature, but not from sexually mature chickens. Taken together, GnIH-R protein expressed in FSH $\beta$ or LH $\beta$ mRNA containing cells is likely to mediate the inhibitory effect of GnIH on LH and FSH secretion (Maddineni et al., 2008) (Figure 1).

To clarify the functional significance of GnIH in the control of avian reproduction, Ubuka et al. (2006) investigated the action of GnIH on the HPG axis in male quail. It is generally accepted that in avian species LH stimulates the formation of T by Leydig cells. FSH and T stimulate growth, differentiation and spermatogenetic activity of the testis (Follett, 1984; Johnson, 1986). LH is a protein complex, which is made of gonadotropin common $\alpha$ and $\mathrm{LH} \beta$ subunits, whereas FSH is a complex of gonadotropin common $\alpha$ and FSH $\beta$ subunits. Peripheral administration of $\mathrm{GnIH}$ to mature quail via osmotic pumps for 2 weeks decreased the expression of gonadotropin common $\alpha$ and LH $\beta$ subunit mRNAs in the pituitary. Concentrations of plasma LH and T were also decreased dose-dependently. Furthermore, administration of $\mathrm{GnIH}$ to mature birds induced testicular apoptosis and decreased spermatogenetic activity in the testis. In immature birds, daily administration of $\mathrm{GnIH}$ for 2 weeks suppressed testicular growth and the rise in the concentration of plasma T. An inhibition of molt by juveniles also occurred after $\mathrm{GnIH}$ administration. These results show that GnIH may inhibit gonadal development and maintenance and also sexual development of birds by decreasing the synthesis and release of gonadotropins (Ubuka et al., 2006) (Figure 1).

\section{REGULATION OF GnIH AND GnIH-R \\ BY MELATONIN}

Based on reports showing inhibitory effects of melatonin on the reproductive activities of quail (Ohta et al., 1989; Guyomarc'h et al., 2001), chicken (Rozenboim et al., 2002) and considering GnIH's inhibitory effects on the secretion of gonadotropins, Ubuka et al. (2005) hypothesized that melatonin may be involved in the induction of $\mathrm{GnIH}$ expression, thus influencing gonadotropin secretion. Px plus Ex decreased the expression of GnIH precursor mRNA and the content of mature GnIH peptide in the hypothalamus and melatonin administration to Px plus Ex birds caused a dose-dependent increase in the expression of GnIH precursor mRNA and the production of mature peptide. The mRNA of $\mathrm{Mel}_{1 \mathrm{c}}$, a melatonin receptor subtype, was expressed in GnIH-ir neurons in the PVN, and autoradiography of melatonin receptors revealed specific binding of melatonin in the PVN. Accordingly, melatonin appears to act directly on $\mathrm{GnIH}$ neurons through its receptor to induce expression of $\mathrm{GnIH}$ (Ubuka et al., 2005) (Figure 1).

Chowdhury et al. (2010) further investigated the role of melatonin in the regulation of $\mathrm{GnIH}$ release. Melatonin administration dose-dependently increased $\mathrm{GnIH}$ release from hypothalamic explants in vitro. GnIH release during the dark period was greater than that during the light period in explants from quail exposed to long day photoperiods. Conversely, plasma LH concentration decreased during the dark period. GnIH release increased under short day photoperiods, when the duration of nocturnal secretion of melatonin increases. These results indicate that melatonin plays a role in stimulating not only $\mathrm{GnIH}$ expression but also $\mathrm{GnIH}$ release, thus reducing plasma $\mathrm{LH}$ concentration in scotophase (Chowdhury et al., 2010) (Figure 1).

\section{BY STRESS}

Stress leads to reproductive dysfunction in many species. Calisi et al. (2008) hypothesized that stress effects upon reproduction are mediated via the hypothalamic GnIH system in birds. They examined the effects of capture-handling stress in the hypothalamus of male and female adult house sparrows. There were more GnIH-ir neurons in fall birds versus those sampled in the spring, and a significant increase in $\mathrm{GnIH}$-ir neurons was seen in stressed birds in spring. These data imply an influence of stress upon the $\mathrm{GnIH}$ system that changes over the annual cycle of reproduction (Calisi et al., 2008) (Figure 1).

\section{BY SEX STEROIDS}

Maddineni et al. (2008) characterized the expression of GnIH-R mRNA and protein in the chicken pituitary gland, and determined whether sexual maturation and gonadal steroids influence pituitary GnIH-R mRNA abundance. GnIH-R mRNA quantity was significantly higher in the pituitaries of sexually immature chickens relative to sexually mature chickens. Estradiol or a combination of estradiol and progesterone treatment caused a significant decrease in pituitary GnIH-R mRNA quantity relative to vehicle controls. These results suggest that GnIH-R gene expression is down-regulated in response to a surge in circulating estradiol and progesterone levels as the chicken undergoes sexual maturation to allow gonadotropin secretion (Maddineni et al., 2008) (Figure 1).

\section{BY SOCIAL INTERACTION}

Calisi et al. (2011) experimentally manipulated nesting opportunities for pairs of European starlings and examined brain $\mathrm{GnIH}$ mRNA and GnIH content, as well as GnRH content and plasma $\mathrm{T}$ and corticosterone. By limiting the number of nest boxes per enclosure and thus the number of social pairing and nesting opportunities, they observed that birds with nest boxes had significantly fewer numbers of GnIH peptide-producing cells than those without nest boxes and this relationship changed with breeding stage. GnRH content, T and corticosterone did not vary with nest box ownership. These data suggest that GnIH may serve as a modulator of reproductive behaviors without dramatically changing the HPG axis in response to social environment (Calisi et al., 2011).

\section{CONCLUSION}

As we reviewed here, the reproductive physiology and behavior of birds are exquisitely regulated by various environmental signals to maximize fitness. Social interactions within the species also have dramatic effects on reproductive physiology and behavior of birds. Indispensable factors for reproduction, such as the establishment of territories, interactions with the opposite sex, and food availability seem to be very important to the timing of breeding. We attempted to understand how environmental information and social interactions are integrated to regulate the HPG axis in birds. 
We concentrated on the two hypothalamic neuropeptide system ( $\mathrm{GnRH}$ and $\mathrm{GnIH}$ neuronal systems) in this review to understand a central mechanism regulating seasonal reproduction (Figure 1). There are still many missing links in understanding how $\mathrm{GnRH}$ and $\mathrm{GnIH}$ neuronal systems integrate various external and internal environmental information and control gonadotropin secretion to time seasonal reproduction in birds. Environmental and social milieus fluctuate seasonally in the wild. Accordingly, coordination of various known and unknown neural and hormonal mechanisms may be needed to translate various environmental

\section{REFERENCES}

Abraham, U., Albrecht, U., Gwinner, E., and Brandstätter, R. (2002). Spatial and temporal variation of passer Per2 gene expression in two distinct cell groups of the suprachiasmatic hypothalamus in the house sparrow (Passer domesticus). Eur. J. Neurosci. 16, 429-436.

Akutsu, S., Takada, M., OhkiHamazaki, H., Murakami, S., and Arai, Y. (1992). Origin of luteinizing hormone-releasing hormone (LHRH) neurons in the chick embryo: effect of the olfactory placode ablation. Neurosci. Lett. 142, 241-244.

Aste, N., Cozzi, B., Stankov, B., and Panzica, G. (2001). Sexual differences and effect of photoperiod on melatonin receptor in avian brain. Microsc. Res. Tech. 55, 37-47.

Baker, J. R. (1938). "The evolution of breeding seasons," in Evolution: Essays on Aspects of Evolutionary Biology, ed G. R. de Beer (London: Oxford University Press), 161-177.

Balthazart, J., Hendrick, J. C., and Deviche, P. (1977). Diurnal variations of plasma gonadotrophins in male domestic ducks during the sexual cycle. Gen. Comp. Endocrinol. 32, 376-389.

Barrett, R. K., and Takahashi, J. S. (1997). Lability of circadian pacemaker amplitude in chick pineal cells: a temperature-dependent process. J. Biol. Rhythms 12, 309-318.

Bartholomew Jr. G. A. (1949). The effect of light intensity and day length on reproduction in the English sparrow. Bull. Mus. Comp. Zoo. (Harvard) 101, 433-476.

Bentley, G. E. (2001). Unraveling the enigma: the role of melatonin in seasonal processes in birds. Microsc. Res. Tech. 53, 63-71.

Bentley, G. E., and Ball, G. F. (2000). Photoperiod-dependent and -independent regulation of melatonin receptors in the forebrain of songbirds. J. Neuroendocrinol. 12, 745-752.

Bentley, G. E., Dawson, A., and Goldsmith, A. R. (2000a). Lack of gonadotrophin-releasing hormone (GnRH) neuron response to decreasing photoperiod in thyroidectomized male starlings (Sturnus vulgaris). J. Exp. Zool. 287, 74-79.

Bentley, G. E., Wingfield, J. C., Morton, M. L., and Ball, G. F. (2000b). Stimulatory effects on the reproductive axis in female songbirds by conspecific and heterospecific male song. Horm. Behav. 37, 179-189.

Bentley, G. E., Goldsmith, A. R., Dawson, A., Briggs, C., and Pemberton, M. (1998). Decreased light intensity alters the perception of day length by male European starlings (Sturnus vulgaris). J. Biol. Rhythms 13, 148-158.

Bentley, G. E., Goldsmith, A. R., Dawson, A., Glennie, L. M., Talbot, R. T., and Sharp, P. J. (1997). Photorefractoriness in European starlings (Sturnus vulgaris) is not dependent upon the long-dayinduced rise in plasma thyroxine. Gen. Comp. Endocrinol. 107, 428-438.

Bentley, G. E., Jensen, J. P., Kaur, G. J., Wacker, D. W., Tsutsui, K., and Wingfield, J. C. (2006). Rapid inhibition of female sexual behavior by gonadotropin-inhibitory hormone (GnIH). Horm. Behav. 49, 550-555.

Bentley, G. E., Perfito, N., and Calisi, R. M. (2012). Seasonand context-dependent sex differences in melatonin receptor activity in a forebrain song control nucleus. Horm. Behav. doi: 10.1016/j.yhbeh.2012.11.015. [Epub ahead of print].

Bentley, G. E., Perfito, N., Ukena, K., Tsutsui, K., and Wingfield, J. C. (2003). Gonadotropin-inhibitory peptide in song sparrows (Melospiza melodia) in different reproductive conditions, and in house sparrows (Passer domesticus) relative to chicken-gonadotropin-releasing hormone. J. Neuroendocrinol. 15, 794-802.

Bern, H. A., Nishioka, R. S., Mewaldt, L. R., and Farner, D. S. (1966).

information and social interactions to produce appropriatelytimed changes in the reproductive physiology and behavior of birds.

\section{ACKNOWLEDGMENTS}

This work was supported by Grants-in-Aid for Scientific Research from the Ministry of Education, Science and Culture, Japan (23570091 to Takayoshi Ubuka; 22132004 and 22227002 to Kazuyoshi Tsutsui), and NSF (IOS 0956338 and 1122044 to George E. Bentley).

Photoperiodic and osmotic influences on the ultrastructure of the hypothalamic neurosecretory system of the white-crowned sparrow, Zonotrichia leucophrys gambelii. Zeitschrift für Zellforschung 69 , 198-227.

Binkley, S., Reilly, K. B., and Hryschchyshyn, M. (1980). Nacetyltransferase in the chick retina. I. Circadian rhythms controlled by environmental lighting are similar to those in the pineal gland. J. Comp. Physiol. 139, 103-108.

Bissonnette, T. H. (1931). Studies on the sexual cycle in birds. V. Effects of light of different intensities upon the testis activity of the European starling (Sturnus vulgaris). Physiol. Zool. 4, 542-574.

Brandstätter, R., Kumar, V., Abraham, U., and Gwinner, E. (2000). Photoperiodic information acquired and stored in vivo is retained in vitro by a circadian oscillator, the avian pineal gland. Proc. Natl. Acad. Sci. U.S.A. 97, 12324-12328.

Brandstätter, R., Kumar, V., Van't Hof, T. J., and Gwinner, E. (2001). Seasonal variations of in vivo and in vitro melatonin production in a passeriform bird, the house sparrow (Passer domesticus). J. Pineal. Res. 31, 120-126.

Bronson, F. H. (1990). Mammalian Reproductive Biology. Chicago, IL: University of Chicago Press.

Burgus, R., Butcher, M., Amoss, M., Ling, N., Monahan, M., Rivier, J., et al. (1972). Primary structure of the ovine hypothalamic luteinizing hormone-releasing factor (LRF). Proc. Natl. Acad. Sci. U.S.A. 69, 278-282.

Burke, W. H., Licht, P., Papkoff, H., and Bona-Gallo, A. (1979). Isolation and characterization of luteinizing hormone and follicle-stimulating hormone from pituitary glands of the turkey (Meleagris gallopavo). Gen. Comp. Endocrinol. 37, 508-520.

Calisi, R. M., Díaz-Muñoz, S. L., Wingfield, J. C., and Bentley, G. E. (2011). Social and breeding status are associated with the expression of GnIH. Genes Brain Behav. 10, 557-564.

Calisi, R. M., Rizzo, N. O., and Bentley, G. E. (2008). Seasonal differences in hypothalamic EGR1 and GnIH expression following capture-handling stress in house sparrows (Passer domesticus). Gen. Comp. Endocrinol. 157, 283-287.

Cassone, V. M., and Moore, R. Y. (1987). Retinohypothalamic projection and suprachiasmatic nucleus of the house sparrow, Passer domesticus. J. Comp. Neurol. 266, 171-182.

Chabot, C. C., and Menaker, M. (1992). Effects of physiological cycles of infused melatonin on circadian rhythmicity in pigeons. J. Comp. Physiol. A 170, 615-622.

Cheng, M. F. (1979). "Progress and prospect in ring dove research: a personal view," in Advances in the Study of Behavior, Vol. 9, eds J. S. Rosenblatt, R. A. Hinde, C. Beer, and M. C. Busnel (New York, NY: Academic Press), 97-129.

Chowdhury, V. S., Yamamoto, K., Ubuka, T., Bentley, G. E. Hattori, A., and Tsutsui, K. (2010). Melatonin stimulates the release of gonadotropin-inhibitory hormone by the avian hypothalamus. Endocrinology 151, 271-280.

Ciccone, N. A., Dunn, I. C., Boswell, T., Tsutsui, K., Ubuka, T., Ukena, K., et al. (2004). Gonadotrophin inhibitory hormone depresses gonadotrophin alpha and folliclestimulating hormone beta subunit expression in the pituitary of the domestic chicken. J. Neuroendocrinol. 16, 999-1006.

Clerens, S., D’Hondt, E., Berghman, L. R., Vandesande, F., and Arckens, L. (2003). Identification of cGnRH-II in the median eminence of Japanese quail (Coturnix coturnix japonica). Gen. Comp. Endocrinol. 131, 48-56.

Collin, J. P., and Oksche, A. (1981). "Structural and functional relationships in the nonmammalian pineal gland," in The Pineal Gland v.1. Anatomy and Biochemistry, ed R. J. Reiter (Boca Raton, FL: CRC press), 27-67. 
Crews, D., and Silver, R. (1985). "Reproductive physiology and behavior interactions in nonmammalian vertebrates," in Handbook of Behavioral Neurobiology, Vol. 7, eds N. Adler, D. Pfaff, and R. Goy (New York, NY: Plenum), 101-182.

Dawson, A. (1984). Changes in plasma thyroxine concentrations in male and female starlings (Sturnus vulgaris) during a photoinduced gonadal cycle. Gen. Comp. Endocrinol. 56, 193-197.

Dawson, A. (1997). Plasma-luteinizing hormone and prolactin during circannual rhythms of gonadal maturation and molt in male and female European starlings. J. Biol. Rhythms $12,371-377$.

Dawson, A. (1998a). Photoperiodic control of the termination of breeding and the induction of moult in House sparrows Passer domesticus. Ibis 140, 35-40.

Dawson, A. (1998b). Thyroidectomy of house sparrows (Passer domesticus) prevents photo-induced testicular growth but not the increased hypothalamic gonadotrophinreleasing hormone. Gen. Comp. Endocrinol. 110, 196-200.

Dawson, A. (2005). The effect of temperature on photoperiodically regulated gonadal maturation, regression and moult in starlings potential consequences of climate change. Funct. Ecol. 19, 995-1000.

Dawson, A., and Goldsmith, A. R. (1983). Plasma prolactin and gonadotrophins during gonadal development and the onset of photorefractoriness in male and female starlings (Sturnus vulgaris) on artificial photoperiods. J. Endocrinol. 97, 253-260.

Dawson, A., and Goldsmith, A. R. (1984). Effects of gonadectomy on seasonal changes in plasma $\mathrm{LH}$ and prolactin concentrations in male and female starlings (Sturnus vulgaris). J. Endocrinol. 100, 213-218.

Dawson, A., and Goldsmith, A. R. (1997). Changes in gonadotrophinreleasing hormone (GnRH-I) in the pre-optic area and median eminence of starlings (Sturnus vulgaris) during the recovery of photosensitivity and during photostimulation. J. Reprod. Fertil. 111, 1-6.

Dawson, A., and McNaughton, F. J. (1993). Circannual rhythms in starlings: response of castrated birds to 12-hr days depends on photoperiodic history. J. Biol. Rhythms 8, 141-150.

Dawson, A., Follett, B. K., Goldsmith, A. R., and Nicholls, T. J. (1985). Hypothalamic gonadotrophin-releasing hormone and pituitary and plasma FSH and prolactin during photostimulation and photorefractoriness in intact and thyroidectomized starlings (Sturnus vulgaris). J. Endocrinol. 105, 71-77.

Dawson, A., Goldsmith, A. R., Nicholls, T. J., and Follett, B. K. (1986). Endocrine changes associated with the termination of photorefractoriness by short daylengths and thyroidectomy in starlings (Sturnus vulgaris). J. Endocrinol. 110, 73-79.

Dawson, A., King, V. M., Bentley, G. E., and Ball, G. F. (2001). Photoperiodic control of seasonality in birds. J. Biol. Rhythms 16, 365-380.

Dawson, A., and Thapliyal, J. P. (2001). "The thyroid and photoperiodism," in Avian Endocrinology, eds A. Dawson and C. M. Chatruvedi (New Delhi: Narosa), 141-151.

Dockray, G. J., Reeve, J. R. Jr., Shively, J., Gayton, R. J., and Barnard, C. S. (1983). A novel active pentapeptide from chicken brain identified by antibodies to FMRFamide. Nature $305,328-330$

Doi, M., Nakajima, Y., Okano, T., and Fukada, Y. (2001). Light-induced phase-delay of the chicken pineal circadian clock is associated with the induction of cE4bp4, a potential transcriptional repressor of $\mathrm{cPer} 2$ gene. Proc. Natl. Acad. Sci. U.S.A. 98, 8089-8094.

Dunn, I. C., Chen, Y., Hook, C., Sharp, P. J., and Sang, H. M. (1993). Characterization of the chicken preprogonadotrophinreleasing hormone-I gene. J. Mol. Endocrinol. 11, 19-29.

Dunn, I. C., and Sharp, P. J. (1999). Photo-induction of hypothalamic gonadotrophin releasing hormone-I mRNA in the domestic chicken: a role for oestrogen? J. Neuroendocrinol. 11, 371-375.

El Halawani, M. E., Kang, S. W., Leclerc, B., Kosonsiriluk, S., and Chaiseha, Y. (2009). Dopaminemelatonin neurons in the avian hypothalamus and their role as photoperiodic clocks. Gen. Comp. Endocrinol. 163, 123-127.

Farner, D. S., and Follett, B. K. (1979). "Reproductive periodicity in birds," in Hormones and Evolution, Vol. 2, ed E. J. W. Barrington (New York, NY: Academic Press), 829-872.

Follett, B. K. (1973). Circadian rhythms and photoperiodic time measurement in birds. J. Reprod. Fertil. Suppl. 19, 5-18.

Follett, B. K. (1976). Plasma follicle-stimulating hormone during photoperiodically induced sexual maturation in male Japanese quail. J. Endocrinol. 69, 117-126.

Follett, B. K. (1984). "Birds," in Marshall's Physiology of Reproduction, 4th Edn., Vol. 1, ed G. E. Lamming (New York, NY: Churchill-Livingstone), 283-350.

Follett, B. K., and Nicholls, T. J. (1988). Acute effect of thyroid hormones in mimicking photoperiodically induced release of gonadotropins in Japanese quail. J. Comp. Physiol. B Biochem. Syst. Environ. Physiol. 157, 837-843.

Follett, B. K., and Robinson, J. E. (1980). "Photoperiod and gonadotropin secretion in birds," in Progress in Reproductive BiologySeasonal Reproduction in Higher Vertebrates, eds R. J. Reiter and B. K. Follett (Basel: Karger), 39-61.

Follett, B. K., Davies, D. T., and Gledhill, B. (1977). Photoperiodic control of reproduction in Japanese quail: changes in gonadotrophin secretion on the first day of induction and their pharmacological blockade. J. Endocrinol. 74, 449-460.

Follett, B. K., Mattocks, P. W., and Farner, D. S. (1974). Circadian function in the photoperiodic induction of gonadotropin secretion in the white-crowned sparrow. Proc. Natl. Acad. Sci. U.S.A. 71, 1666-1669.

Follett, B. K., and Sharp, P. J. (1969). Circadian rhythmicity in photoperiodically induced gonadotrophin release and gonadal growth in the quail. Nature 223, 968-971.

Follett, B. K., Scanes, C. G., and Cunningham, F. J. (1972). A radioimmunoassay for avian luteinizing hormone. J. Endocrinol. 52, 359-378.

Fukada, Y., and Okano, T. (2002) Circadian clock system in the pineal gland. Mol. Neurobiol. 25, 19-30.

Gibson, W. R., Follett, B. K., and Gledhill, B. (1975). Plasma levels of luteinizing hormone in gonadectomized Japanese quail exposed to short or to long daylengths. J. Endocrinol. 64, 87-101.

Goldman, B. D. (2001). Mammalian photoperiodic system: formal properties and neuroendocrine mechanisms of photoperiodic time measurement. J. Biol. Rhythms 16, 283-301.

Goldsmith, A. R., and Nicholls, T. J. (1992). Thyroxine effects upon reproduction, prolactin secretion and plumage moult in thyroidectomised European starlings Sturnus vulgaris. Ornis. Scand. 23, 398-404.

Greives, T. J., Kingma, S. A., Beltrami, G., and Hau, M. (2012). Melatonin delays clutch initiation in a wild songbird. Biol. Lett. 8, 330-332.

Guyomarc'h, C., and Guyomarc'h, J. C. (1995). Moulting cycles in European quail (Coturnix coturnix coturnix) under constant photoperiodic conditions. Biol. Rhythm Res. 26, 292-305.

Guyomarc'h, C., Lumineau, S. Vivien-Roels, B., Richard, J., and Deregnaucourt, S. (2001). Effect of melatonin supplementation on the sexual development in European quail (Coturnix coturnix). Behav. Processes 53, 121-130.

Gwinner, E. (1986). Circannual Clocks. Berlin: Springer-Verlag.

Gwinner, E. (1996). Circannual clocks in avian reproduction and migration. Ibis 138, 47-63.

Gwinner, E. (2003). Circannual rhythms in birds. Curr. Opin. Neurobiol. 13, 770-778.

Gwinner, E., and Dittami, J. (1990). Endogenous reproductive rhythms in a tropical bird. Science 249, 906-908.

Hamm, H. E., and Menaker, M. (1980). Retinal rhythms in chicks: circadian variation in melatonin and serotonin $\mathrm{N}$-acetyltransferase activity. Proc. Natl. Acad. Sci. U.S.A. 77, 4998-5002.

Hattori, A., Ishii, S., and Wada, M. (1986). Effects of two kinds of chicken luteinizing hormonereleasing hormone (LH-RH), mammalian LH-RH and its analogs on the release of $\mathrm{LH}$ and $\mathrm{FSH}$ in Japanese quail and chicken. Gen. Comp. Endocrinol. 64, 446-455.

Hattori, A., Ishii, S., Wada, M., Miyamoto, K., Hasegawa, Y., Igarashi, M., et al. (1985). Effects of chicken (Gln8)- and mammalian (Arg8)-luteinizing hormone-releasing hormones on the release of gonadotrophins in vitro and in vivo from the adenohypophysis of Japanese quail. Gen. Comp. Endocrinol. 59, 155-161.

Hinde, R. A. (1965). "Interaction of internal and external factors in integration of canary reproduction," in Sex and Behavior, ed F. A. Beach (New York, NY: John Wiley), 381-415.

Hinuma, S., Shintani, Y., Fukusumi, S., Iijima, N., Matsumoto, Y., Hosoya, M., et al. (2000). New neuropeptides containing carboxy-terminal RFamide and their receptor in mammals. Nat. Cell Biol. 2, 703-708.

Huang, Y. M., Shi, Z. D., Liu, Z., Liu, Y., and Li, X. W. (2008). Endocrine regulations of reproductive seasonality, follicular development and 
incubation in Magang geese. Anim. Reprod. Sci. 104, 344-358.

Immelmann, K. (1971). "Ecological aspects of photoperiodic reproduction," in Avian Biology, Vol. 1, eds D. S. Farner and J. R. King (New York, NY: Academic Press), 341-389.

Johnson, A. L. (1986). "Reproduction in the male," in Avian Physiology, 4th $E d n$., ed P. D. Sturkie (New York, NY: Springer-Verlag), 432-451.

Joseph, N. T., Morgan, K., Sellar, R., McBride, D., Millar, R. P., and Dunn, I. C. (2009). The chicken type III GnRH receptor homologue is predominantly expressed in the pituitary, and exhibits similar ligand selectivity to the type I receptor. J. Endocrinol. 202, 179-190.

Juss, T. S., Meddle, S. L., Servant, R. S., and King, V. M. (1993). Melatonin and photoperiodic time measurement in Japanese quail (Coturnix coturnix japonica). Proc. Biol. Sci. 254, 21-28.

Kameda, Y., Miura, M., and Maruyama, S. (2002). Effect of pinealectomy on the photoperiod-dependent changes of the specific secretory cells and alpha-subunit mRNA level in the chicken pars tuberalis. Cell Tissue Res. 308, 121-130.

Kang, S. W., Thayananuphat, A., Bakken, T., and El Halawani, M. E. (2007). Dopamine-melatonin neurons in the avian hypothalamus controlling seasonal reproduction. Neuroscience 150, 223-233.

Kang, S. W., Thayananuphat, A., Rozenboim, I., Millam, J. R., Proudman, J. A., and El Halawani, M. E. (2006). Expression of hypothalamic GnRH-I mRNA in the female turkey at different reproductive states and following photostimulation. Gen. Comp. Endocrinol. 146, 91-99.

King, J. A., and Millar, R. P. (1982a). Structure of chicken hypothalamic luteinizing hormone-releasing hormone. I. Structural determination on partially purified material. J. Biol. Chem. 257, 10722-10728.

King, J. A., and Millar, R. P. (1982b). Structure of chicken hypothalamic luteinizing hormone-releasing hormone. II. Isolation and characterization. J. Biol. Chem. 257, 10729-10732.

King, J. A., Davidson, J. S., Mehl, A. E., Wakefield, I. K., Andersson, P. B., and Millar, R. P. (1989a). Gonadal steroid modulation of signal transduction and luteinizing hormone release in cultured chicken pituitary cells. Endocrinology 124, 1830-1840.

King, J. A., Mehl, A. E., TyndaleBiscoe, C. H., Hinds, L., and
Millar, R. P. (1989b). A second form of gonadotropin-releasing hormone $(\mathrm{GnRH})$, with chicken GnRH II-like properties, occurs together with mammalian GnRH in marsupial brains. Endocrinology 125, 2244-2252.

Kobayashi, M., Ito, T., Ishii, S., and Wada, M. (2004). Seasonal change in luteinizing hormone subunit mRNA in Japanese quail and effects of short daylength and low temperature. Gen. Comp. Endocrinol. 139, 38-47.

Lack, D. (1968). Ecological Adaptations for Breeding in Birds. London: Methuen.

Lehrman, D. S. (1965). "Interaction between internal and external environments in the regulation of the reproductive cycle of the ring dove," in Sex and Behavior, ed F. Beach (New York, NY: Wiley), 355-380.

Leopold, A. S., Erwin, M., Oh, J., and Browning, B. (1976). Phytoestrogens: adverse effects on reproduction in California quail. Science 191, 98-100

Li, Q., Tamarkin, L., Levantine, P., and Ottinger, M. A. (1994). Estradiol and androgen modulate chicken luteinizing hormone-releasing hormone-I release in vitro. Biol. Reprod. 51, 896-903.

Maddineni, S., Ocón-Grove, O. M., Krzysik-Walker, S. M., Hendricks G. L. 3rd, Proudman, J. A., and Ramachandran, R. (2008). Gonadotrophin-inhibitory hormone receptor expression in the chicken pituitary gland: potential influence of sexual maturation and ovarian steroids. J. Neuroendocrinol. 20, 1078-1088.

Maney, D. L., Goode, C. T., Lake, J. I., Lange, H. S., and O'Brien, S. (2007). Rapid neuroendocrine responses to auditory courtship signals. Endocrinology 148, 5614-5623.

Maney, D. L., Richardson, R. D., and Wingfield, J. C. (1997) Central administration of chicken gonadotropin-releasing hormone-II enhances courtship behavior in a female sparrow. Horm. Behav. 32, 11-18.

Mantei, K. E., Ramakrishnan, S., Sharp, P. J., and Buntin, J. D. (2008). Courtship interactions stimulate rapid changes in GnRH synthesis in male ring doves. Horm. Behav. 54, 669-675.

Marshall, A. J. (1970). "Environmental factors other than light involved in the control of sexual cycle in birds and mammals," in $\mathrm{La}$ Photorégulation de la Reproduction chez les Oiseaux et les Mammiféres, eds J. Benoit and I. Assenmacher (Paris: CNRS), 53-65.

Marshall, F. H. A. (1936). Sexual periodicity and the causes which determine it. Philos. Trans. R. Soc. Lond. B 226, 423-456.

Maruska, K. P., and Fernald, R. D. (2011). Social regulation of gene expression in the hypothalamicpituitary-gonadal axis. Physiology (Bethesda) 26, 412-423.

Matsuo, H., Baba, Y., Nair, R. M. Arimura, A., and Schally, A. V. (1971). Structure of the porcine LH- and FSH-releasing hormone. I. The proposed amino acid sequence. Biochem. Biophys. Res. Commun. 43 1334-1339.

Mattocks, P. W. Jr, Farner, D. S. and Follett, B. K. (1976). The annual cycle in luteinizing hormone in the plasma of intact and castrated white-crowned sparrows, Zonotrichia leucophrys gambelii. Gen. Comp. Endocrinol. 30, 156-161.

Meddle, S. L., and Follett, B. K. (1997). Photoperiodically driven changes in Fos expression within the basal tuberal hypothalamus and median eminence of Japanese quail. J. Neurosci. 17, 8909-8918.

Meddle, S. L., Maney, D. L., and Wingfield, J. C. (1999). Effects of N-methyl-D-aspartate on luteinizing hormone release and Fos-like immunoreactivity in the male white-crowned sparrow (Zonotrichia leucophrys gambelii). Endocrinology 140, 5922-5928.

Mikami, S., Yamada, S., Hasegawa, Y., and Miyamoto, K. (1988). Localization of avian LHRHimmunoreactive neurons in the hypothalamus of the domestic fowl, Gallus domesticus, and the Japanese quail, Coturnix coturnix. Cell Tissue Res. 251, 51-58.

Mikami, S.-I., Oksche, A., Farner, D. S., and Vitums, A. (1970) Fine structure of the vessels of the hypohysial portal system of the white-crowned sparrow, Zonotrichia leucophrys gambelii. Zeitschrift für Zellforschung 106, 155-174.

Millar, R. P. (2003). GnRH II and type II GnRH receptors. Trends Endocrinol. Metab. 14, 35-43.

Millar, R. P. (2005). GnRHs and GnRH receptors. Anim. Reprod. Sci. 88 5-28.

Millar, R. P., and King, J. A. (1983) Synthesis and biological activity of [D-Trp6] chicken luteinizing hormone-releasing hormone. Peptides 4, 425-429.

Millar, R. P., Lu, Z. L., Pawson, A. J., Flanagan, C. A., Morgan,
K., and Maudsley, S. R. (2004). Gonadotropin-releasing hormone receptors. Endocr. Rev. 25, 235-275. Miyamoto, K., Hasegawa, Y., Minegishi, T., Nomura, M., Takahashi, Y., Igarashi, M., et al. (1982). Isolation and characterization of chicken hypothalamic luteinizing hormonereleasing hormone. Biochem. Biophys. Res. Commun. 107, 820-827.

Miyamoto, K., Hasegawa, Y., Nomura, M., Igarashi, M., Kangawa, K., and Matsuo, H. (1984). Identification of the second gonadotropin-releasing hormone in chicken hypothalamus: evidence that gonadotropin secretion is probably controlled by two distinct gonadotropinreleasing hormones in avian species. Proc. Natl. Acad. Sci. U.S.A. 81, 3874-3878.

Morgan, K., and Millar, R. P. (2004). Evolution of GnRH ligand precursors and GnRH receptors in protochordate and vertebrate species. Gen. Comp. Endocrinol. 139, 191-197.

Murakami, N., Nakamura, H., Nishi, R., Marumoto, N., and Nasu, T. (1994). Comparison of circadian oscillation of melatonin release in pineal cells of house sparrow, pigeon and Japanese quail, using cell perfusion systems. Brain Res. 651, 209-214.

Nakane, Y., Ikegami, K., Ono, H., Yamamoto, N., Yoshida, S. Hirunagi, K., et al. (2010). A mammalian neural tissue opsin (Opsin 5) is a deep brain photoreceptor in birds. Proc. Natl. Acad. Sci. U.S.A. 107, 15264-15268.

Nakao, N., Ono, H., Yamamura, T., Anraku, T., Takagi, T., Higashi, K., et al. (2008a). Thyrotrophin in the pars tuberalis triggers photoperiodic response. Nature 452, 317-322.

Nakao, N., Ono, H., and Yoshimura, T. (2008b). Thyroid hormones and seasonal reproductive neuroendocrine interactions. Reproduction $136,1-8$.

Nicholls, T. J. (1974). Changes in plasma LH levels during a photoperiodically controlled reproductive cycle in the canary (Serinus canarius). Gen. Comp. Endocrinol. 24, 442-445.

Nicholls, T. J., Follett, B. K., and Robinson, J. E. (1983). A photoperiodic response in gonadectomized Japanese quail exposed to a single long day. J. Endocrinol. 97, 121-126. Nicholls, T. J., Goldsmith, A. R., and Dawson, A. (1988). Photorefractoriness in birds and comparison with mammals. Physiol. Rev. 68, 133-176. 
Nicholls, T. J., and Storey, C. R. (1976). The effects of castration on plasma LH levels in photosensitive and photorefractory canaries (Serinus canarius). Gen. Comp. Endocrinol. 29, 170-174.

Norgren, R. B. Jr., and Lehman, M. N. (1991). Neurons that migrate from the olfactory epithelium in the chick express luteinizing hormonereleasing hormone. Endocrinology 128, 1676-1678.

Norgren, R. B. Jr., and Silver, R. (1989). Retinohypothalamic projections and the suprachiasmatic nucleus in birds. Brain Behav. Evol. 34, 73-83.

Norgren, R. B. Jr., and Silver, R. (1990). Distribution of vasoactive intestinal peptide-like and neurophysin-like immunoreactive neurons and acetylcholinesterase staining in the ring dove hypothalamus with emphasis on the question of an avian suprachiasmatic nucleus. Cell Tissue Res. 259, 331-339.

Ohta, M., Kadota, C., and Konishi, H. (1989). A role of melatonin in the initial stage of photoperiodism in the Japanese quail. Biol. Reprod. 40, 935-941.

Okano, T., and Fukada, Y. (2001). Photoreception and circadian clock system of the chicken pineal gland. Microsc. Res. Tech. 53, 72-80.

Okano, T., Yamamoto, K., Okano, K., Hirota, T., Kasahara, T., Sasaki, M., et al. (2001). Chicken pineal clock genes: implication of BMAL2 as a bidirectional regulator in circadian clock oscillation. Genes Cells 6 , 825-836.

Okubo, K., and Nagahama, Y. (2008). Structural and functional evolution of gonadotropin-releasing hormone in vertebrates. Acta Physiol. (Oxf). 193, 3-15.

Oshima, I., Yamada, H., Goto, M., Soto, K., and Ebihara, S. (1989). Pineal and retinal melatonin is involved in the control of circadian locomotor activity and body temperature rhythms in the pigeon. J. Comp. Physiol. A 166, 217-226.

Osugi, T., Ukena, K., Bentley, G. E., O'Brien, S., Moore, I. T., Wingfield, J. C., et al. (2004). Gonadotropin-inhibitory hormone in Gambel's white-crowned sparrow (Zonotrichia leucophrys gambelii): cDNA identification, transcript localization and functional effects in laboratory and field experiments. J. Endocrinol. 182, 33-42.

Panzica, G. C., Fraschini, F., Aste, N., Lucini, V., Viglietti-Panzica, C., Cozzi, B., et al. (1994). The density of melatonin receptors is dependent upon the prevailing photoperiod in the Japanese quail (Coturnix japonica). Neurosci. Lett. 173, 111-114.

Parry, D. M., Goldsmith, A. R., Millar, R. P., and Glennie, L. M. (1997). Immunocytochemical localization of GnRH precursor in the hypothalamus of European starlings during sexual maturation and photorefractoriness. J. Neuroendocrinol. 9, 235-243.

Perfito, N., Bentley, G., and Hau, M. (2006). Tonic activation of brain GnRH immunoreactivity despite reduction of peripheral reproductive parameters in opportunistically breeding zebra finches. Brain Behav. Evol. 67, 123-134.

Perrins, C. M. (1973). Some effects of temperature on breeding in the great tit and manx shearwater. J. Reprod. Fertil. Suppl. 19, 163-173.

Price, D. A., and Greenberg, M. J. (1977). Structure of a molluscan cardioexcitatory neuropeptide. Science 197, 670-671.

Reinert, B. D., and Wilson, F. E. (1996). Thyroid dysfunction and thyroxine-dependent programming of photoinduced ovarian growth in American tree sparrows (Spizella arborea). Gen. Comp. Endocrinol. 103, 71-81.

Reppert, S. M., Weaver, D. R., Cassone, V. M., Godson, C., and Kolakowski L. F. Jr. (1995). Melatonin receptors are for the birds: molecular analysis of two receptor subtypes differentially expressed in chick brain. Neuron 15, 1003-1015.

Robinson, J. E., and Follett, B. K (1982). Photoperiodism in Japanese quail: the termination of seasonal breeding by photorefractoriness. Proc. R. Soc. Lond. B Biol. Sci. 215, 95-116.

Roch, G. J., Busby, E. R., and Sherwood, N. M. (2011). Evolution of GnRH: diving deeper. Gen. Comp. Endocrinol. 171, 1-16.

Rozenboim, I., Aharony, T., and Yahav S. (2002). The effect of melatonin administration on circulating plasma luteinizing hormone concentration in castrated White Leghorn roosters. Poult. Sci. 81, 1354-1359.

Sakai, H., and Ishii, S. (1980). Isolation and characterization of chicken follicle-stimulating hormone. Gen. Comp. Endocrinol. 42, 1-8.

Saldanha, C. J., Silverman, A. J., and Silver, R. (2001). Direct innervation of GnRH neurons by encephalic photoreceptors in birds. J. Biol. Rhythms 16, 39-49.

Satake, H., Hisada, M., Kawada, T., Minakata, H., Ukena, K., and Tsutsui, K. (2001). Characterization of a cDNA encoding a novel avian hypothalamic neuropeptide exerting an inhibitory effect on gonadotropin release. Biochem. J. 354, 379-385.

Scanes, C. G., Godden, P. M., and Sharp, P. J. (1977). An homologous radioimmunoassay for chicken follicle-stimulating hormone: observations on the ovulatory cycle. J. Endocrinol. 73, 473-481.

Schwanzel-Fukuda, M., and Pfaff, D. W. (1989). Origin of luteinizing hormone-releasing hormone neurons. Nature 338, 161-164.

Searcy, W. A. (1992). "Measuring responses of female birds to male song," in Playback and Studies of Animal Communication, ed P. K. McGregor (New York, NY: Plenum) 175-189.

Sharp, P. J., and Klandorf, H. (1981) The interaction between day length and the gonads in the regulation of levels of plasma thyroxine and triiodothyronine in the Japanese quail. Gen. Comp. Endocrinol. 45 504-512.

Sharp, P. J., Talbot, R. T., Main, G M., Dunn, I. C., Fraser, H. M. and Huskisson, N. S. (1990). Physiological roles of chicken LHRH-I and -II in the control of gonadotrophin release in the domestic chicken. J. Endocrinol. 124, 291-299.

Sherwood, N. M., Wingfield, J. C., Ball, G. F., and Dufty, A. M (1988). Identity of gonadotropinreleasing hormone in passerine birds: comparison of $\mathrm{GnRH}$ in song sparrow (Melospiza melodia) and starling (Sturnu vulgaris) with five vertebrate GnRHs. Gen. Comp. Endocrinol. 69 341-351.

Shimizu, M., and Bédécarrats, G. Y. (2006). Identification of a novel pituitary-specific chicken gonadotropin-releasing hormone receptor and its splice variants. Biol. Reprod. 75, 800-808.

Shimizu, M., and Bédécarrats, G. Y (2010). Activation of the chicken gonadotropin-inhibitory hormone receptor reduces gonadotropin releasing hormone receptor signaling. Gen. Comp. Endocrinol. 167 331-337.

Shimizu, T., Cox, K., Karten, H. J., and Britto, L. R. (1994). Cholera toxin mapping of retinal projections in pigeons (Columbia livia), with emphasis on retinohypothalamic connections. Vis. Neurosci. 11, 441-446.

Silver, R., Witkovsky, P., Horvath, P., Alones, V., Barnstable, C. J., and Lehman, M. N. (1988). Coexpression of opsin- and VIP- like-immunoreactivity in CSFcontacting neurons of the avian brain. Cell Tissue Res. 253, 189-198. Small, T. W., Sharp, P. J., Bentley, G. E., Millar, R. P., Tsutsui, K., Mura, E., et al. (2007). Photoperiod-independent hypothalamic regulation of luteinizing hormone secretion in a freeliving sonoran desert bird, the Rufous-winged Sparrow (Aimophila carpalis). Brain Behav. Evol. 71, 127-142.

Son, Y. L., Ubuka, T., Millar, R. P., Kanasaki, H., and Tsutsui, K. (2012). Gonadotropin-inhibitory hormone inhibits GnRH-induced gonadotropin subunit gene transcriptions by inhibiting AC/cAMP/ PKA-dependent ERK pathway in L $\mathrm{RT} 2$ cells. Endocrino$\log y$ 153, 2332-2343.

Stevenson, T. J., Lynch, K. S., Lamba, P., Ball, G. F., and Bernard, D. J. (2009). Cloning of gonadotropinreleasing hormone I complementary DNAs in songbirds facilitates dissection of mechanisms mediating seasonal changes in reproduction. Endocrinology 150, 1826-1833.

Storey, C. R., Nicholls, T. J., and Follett, B. K. (1980). Castration accelerates the rate of onset of photorefractoriness in the canary (Serinus canarius). Gen. Comp. Endocrinol. 42, 315-319.

Sun, Y. M., Dunn, I. C., Baines, E., Talbot, R. T., Illing, N., Millar, R. P., et al. (2001a). Distribution and regulation by oestrogen of fully processed and variant transcripts of gonadotropin releasing hormone I and gonadotropin releasing hormone receptor mRNAs in the male chicken. J. Neuroendocrinol. 13, 37-49.

Sun, Y. M., Flanagan, C. A., Illing, N., Ott, T. R., Sellar, R., Fromme, B. J., et al. (2001b). A chicken gonadotropin-releasing hormone receptor that confers agonist activity to mammalian antagonists. Identification of D-Lys(6) in the ligand and extracellular loop two of the receptor as determinants. J. Biol. Chem. 276, 7754-7761.

Takahashi, J. S., and Menaker, M. (1984). Multiple redundant circadian oscillators within the isolated avian pineal gland. J. Comp. Physiol. A. 154, 435-440.

Tobari, Y., Iijima, N., Tsunekawa, K., Osugi, T., Okanoya, K., Tsutsui, K., et al. (2010). Identification of gonadotropin-inhibitory hormone in the zebra finch (Taeniopygia guttata): peptide isolation, cDNA cloning and brain distribution. Peptides 31, 816-826. 
Tostivint, H. (2011). Evolution of the gonadotropin-releasing hormone (GnRH) gene family in relation to vertebrate tetraploidizations. Gen. Comp. Endocrinol. 170, 575-581.

Tsutsui, K. (2009). Review: a new key neurohormone controlling reproduction, gonadotropin-inhibitory hormone (GnIH): biosynthesis, mode of action and functional significance. Prog. Neurobiol. 88, 76-88.

Tsutsui, K., and Ubuka, T. (2013). "Gonadotropin-inhibitory Hormone," in Handbook of Biologically Active Peptides. Section on Brain Peptides, eds A. J. Kastin and H. Vaudry (London: Academic Press), 802-811.

Tsutsui, K., Bentley, G. E., Bedecarrats, G., Osugi, T., Ubuka, T., and Kriegsfeld, L. J. (2010a). Review: gonadotropin-inhibitory hormone $(\mathrm{GnIH})$ and its control of central and peripheral reproductive function. Front. Neuroendocrinol. 31, 284-295. doi: 10.1016/j.yfrne. 2010.03.001

Tsutsui, K., Bentley, G. E., Kriegsfeld, L. J., Osugi, T., Seong, J. Y., and Vaudry, H. (2010b). Review: discovery and evolutionary history of gonadotrophin-inhibitory hormone and kisspeptin: new key neuropeptides controlling reproduction. J. Neuroendocrinol. 22, 716-727.

Tsutsui, K., Saigoh, E., Ukena, K., Teranishi, H., Fujisawa, Y., Kikuchi, M., et al. (2000). A novel avian hypothalamic peptide inhibiting gonadotropin release. Biochem. Biophys. Res. Commun. 275, 661-667.

Tsutsui, K., and Ukena, K. (2006). Review: hypothalamic LPXRFamide peptides in vertebrates: identification, localization and hypophysiotropic activity. Peptides 27, 1121-1129.

Tsutsui, K., Ubuka, T., Bentley, G. E., and Kriegsfeld, L. J. (2012). Review: gonadotropin-inhibitory hormone (GnIH): discovery, progress and prospect. Gen. Comp. Endocrinol. 177, 305-314.

Tsutsui, K., Ubuka, T., Yin, H., Osugi, T., Ukena, K., Bentley, G. E., et al. (2006). Mode of action and functional significance of avian gonadotropin-inhibitory hormone (GnIH): a review. J. Exp. Zool. 305A, 801-806.

Tsuyoshi, H., and Wada, M. (1992). Termination of $\mathrm{LH}$ secretion in Japanese quail due to high- and low-temperature cycles and short daily photoperiods. Gen. Comp. Endocrinol. 85, 424-449.
Ubuka, T., and Bentley, G. E. (2009). Identification, localization, and regulation of passerine GnRH-I messenger RNA. J. Endocrinol. 201, 81-87.

Ubuka, T., and Bentley, G. E. (2011) "Neuroendocrine control of reproduction in birds," in Hormones and Reproduction of Vertebrates. Birds, Vol. 4, eds D. O. Norris and K. H. Lopez (London: Academic Press), $1-25$.

Ubuka, T., Bentley, G. E., Ukena, K., Wingfield, J. C., and Tsutsui, K. (2005). Melatonin induces the expression of gonadotropininhibitory hormone in the avian brain. Proc. Natl. Acad. Sci. U.S.A. 102, 3052-3057.

Ubuka, T., Cadigan, P. A., Wang, A., Liu, J., and Bentley, G. E. (2009a). Identification of European starling GnRH-I precursor mRNA and its seasonal regulation. Gen. Comp. Endocrinol. 162, 301-306.

Ubuka, T., Lai, H., Kitani, M., Suzuuchi, A., Pham, V., Cadigan, P. A., et al. (2009b). Gonadotropininhibitory hormone identification, cDNA cloning, and distribution in rhesus macaque brain. J. Comp. Neurol. 517, 841-855.

Ubuka, T., Morgan, K., Pawson, A. J., Osugi, T., Chowdhury, V. S., Minakata, H., et al. (2009c). Identification of human GnIH homologs, RFRP-1 and RFRP-3, and the cognate receptor, GPR147 in the human hypothalamic pituitary axis. PLoS ONE 4:e8400. doi: 10.1371/journal.pone.0008400

Ubuka, T., Kim, S., Huang, Y. C., Reid, J., Jiang, J., Osugi, T., et al. (2008a). Gonadotropin-inhibitory hormone neurons interact directly with gonadotropin-releasing hormoneI and -II neurons in European starling brain. Endocrinology 149, 268-278.

Ubuka, T., McGuire, N. L., Calisi, R. M., Perfito, N., and Bentley, G. E. (2008b). The control of reproductive physiology and behavior by gonadotropin-inhibitory hormone. Integr. Comp. Biol. 48, 560-569.

Ubuka, T., Mizuno, T., Fukuda, Y., Bentley, G. E., Wingfield, J. C., and Tsutsui, K. (2013). RNA interference of gonadotropininhibitory hormone gene induces aggressive and sexual behaviors in birds. Gen. Comp. Endocrinol. 181, 179-186.

Ubuka, T., Inoue, K., Fukuda, Y., Mizuno, T., Ukena, K., Kriegsfeld, L. J., et al. (2012a). Identification, expression, and physiological functions of Siberian hamster gonadotropin-inhibitory hormone. Endocrinology 153, 373-385.

Ubuka, T., Mukai, M., Wolfe, J. Beverly, R., Clegg, S., Wang, A., et al. (2012b). RNA interference of gonadotropin-inhibitory hormone gene induces arousal in songbirds. PLoS ONE 7:e30202. doi 10.1371/journal.pone.0030202

Ubuka, T., Son, Y. L., Tobari, Y., and Tsutsui, K. (2012c). Gonadotropininhibitory hormone action in the brain and pituitary. Front. Endocrinol. (Lausanne) 3:148. doi 10.3389/fendo.2012.00148

Ubuka, T., Ueno, M., Ukena, K., and Tsutsui, K. (2003). Developmental changes in gonadotropin-inhibitory hormone in the Japanese quail (Coturnix japonica) hypothalamohypophysial system. J. Endocrinol. 178, 311-318.

Ubuka, T., Ukena, K., Sharp, P. J., Bentley, G. E., and Tsutsui, K. (2006). Gonadotropin-inhibitory hormone inhibits gonadal development and maintenance by decreasing gonadotropin synthesis and release in male quail. Endocrinology 147, 1187-1194.

Ukena, K., Ubuka, T., and Tsutsui, K. (2003). Distribution of a novel avian gonadotropin-inhibitory hormone in the quail brain. Cell Tissue Res. 312, 73-79.

Underwood, H., Barrett, R. K., and Siopes, T. (1990). The quail's eye: a biological clock. J. Biol. Rhythms 5 , 257-265.

Underwood, H., Binkley, S., Siopes, T. and Mosher, K. (1984). Melatonin rhythms in the eyes, pineal bodies, and blood of Japanese quail (Coturnix coturnix japonica). Gen. Comp. Endocrinol. 56, 70-81.

Underwood, H., Steele, C. T., and Zivkovic, B. (2001). Circadian organization and the role of the pineal in birds. Microsc. Res. Tech. 53, 48-62.

van Gils, J., Absil, P., Grauwels, L., Moons, L., Vandesande, F., and Balthazart, J. (1993). Distribution of luteinizing hormone-releasing hormones I and II (LHRH-I and -II) in the quail and chicken brain as demonstrated with antibodies directed against synthetic peptides. J. Comp. Neurol. 334 304-323.

Wada, M., Akimoto, R., and Tsuyoshi, H. (1992). Annual changes in levels of plasma LH and size of cloacal protrusion in Japanese quail (Coturnix coturnix japonica) housed in outdoor cages under natural conditions. Gen. Comp. Endocrinol. 85, 415-423.

Wada, M., Hatanaka, F., Tsuyoshi, H., and Sonoda, Y. (1990). Temperature modulation of photoperiodically induced LH secretion and its termination in Japanese quail (Coturnix coturnix japonica). Gen. Comp. Endocrinol. 80, 465-472.

Wada, Y., Okano, T., and Fukada, Y. (2000). Phototransduction molecules in the pigeon deep brain. J. Comp. Neurol. 428, 138-144.

Wilson, F. E. (1991). Neither retinal nor pineal photoreceptors mediate photoperiodic control of seasonal reproduction in American tree sparrows (Spizella arborea). J. Exp. Zool. 117-127.

Wilson, F. E., and Follett, B. K. (1974). Plasma and pituitary luteinizing hormone in intact and castrated tree sparrows (Spizella arborea) during a photoinduced gonadal cycle. Gen. Comp. Endocrinol. 23, 82-93.

Wilson, F. E., and Reinert, B. D. (1995). The photoperiodic control circuit in euthyroid American tree sparrows (Spizella arborea) is already programmed for photorefractoriness by week 4 under long days. J. Reprod. Fertil. 103, 279-284.

Wilson, F. E., and Reinert, B. D. (2000). Thyroid hormone acts centrally to programme photostimulated male american tree sparrows (Spizella arborea) for vernal and autumnal components of seasonality. J. Neuroendocrinol. 12, 87-95.

Wingfield, J. C. (1983). "Environmental and endocrine control of reproduction: an ecological approach," in Avian Endocrinology: Environmental and Ecological Aspects, eds S. I. Mikami and M. Wada (Tokyo: Japanese Scientific Societies Press; Berlin: Springer-Verlag), 205-288.

Wingfield, J. C. (1993). Control of testicular cycles in the song sparrow, Melospiza melodia: interaction of photoperiod and an endogenous period? Gen. Comp. Endocrinol. 92, 388-401.

Wingfield, J. C., and Farner, D. S. (1980). "Control of seasonal reproduction in temperate-zone birds," in Progress in Reproductive Biology, Vol. 5, eds R. J. Reiter and B. K. Follett (New York, NY: Karger), 62-101.

Wingfield, J. C., Follett, B. K., Matt, K. S., and Farner, D. S. (1980) Effect of day length on plasma FSH and $\mathrm{LH}$ in castrated and intact white-crowned sparrows. Gen. Comp. Endocrinol. 42, 464-470.

Wingfield, J. C., Hahn, T. P., Maney, D. L., Schoech, S. J., Wada, M., and Morton, M. L. (2003). Effects of temperature on photoperiodically 
induced reproductive development, circulating plasma luteinizing hormone and thyroid hormones, body mass, fat deposition and molt in mountain white-crowned sparrows, Zonotrichia leucophrys oriantha. Gen. Comp. Endocrinol. $131,143-158$.

Wingfield, J. C., Whaling, C. S., and Marler, P. R. (1994). "Communication in vertebrate aggression and reproduction: the role of hormones," in The Physiology of Reproduction, eds E. Knobil and J. D. Neil (New York, NY: Raven Press), 303-342.

Wray, S., Grant, P., and Gainer, H. (1989). Evidence that cells expressing luteinizing hormonereleasing hormone mRNA in the mouse are derived from progenitor cells in the olfactory placode. Proc. Natl. Acad. Sci. U.S.A. 86, 8132-8136.

Yamamoto, K., Okano, T., and Fukada, Y. (2001). Chicken pineal Cry genes: light-dependent up-regulation of cCryl and cCry2 transcripts. Neurosci. Lett. 313, 13-16.

Yamamoto, N., Uchiyama, H., OhkiHamazaki, H., Tanaka, H., and Ito, H. (1996). Migration of GnRHimmunoreactive neurons from the olfactory placode to the brain: a study using avian embryonic chimeras. Brain Res. Dev. Brain Res. 95, 234-244.

Yamamura, T., Hirunagi, K., Ebihara, S., and Yoshimura, T. (2004).
Seasonal morphological changes in the neuro-glial interaction between gonadotropin-releasing hormone nerve terminals and glial endfeet in Japanese quail. Endocrinology 145, 4264-4267.

Yamamura, T., Yasuo, S., Hirunagi, K., Ebihara, S., and Yoshimura, T. (2006). T(3) implantation mimics photoperiodically reduced encasement of nerve terminals by glial processes in the median eminence of Japanese quail. Cell Tissue Res. 324, 175-179.

Yasuo, S., Watanabe, M., Nakao, N., Takagi, T., Follett, B. K., Ebihara, S., et al. (2005). The reciprocal switching of two thyroid hormoneactivating and -inactivating enzyme genes is involved in the photoperiodic gonadal response of Japanese quail. Endocrinology 146, 2551-2554.

Yasuo, S., Watanabe, M., Okabayashi, N., Ebihara, S., and Yoshimura, T. (2003). Circadian clock genes and photoperiodism: comprehensive analysis of clock gene expression in the mediobasal hypothalamus, the suprachiasmatic nucleus, and the pineal gland of Japanese quail under various light schedules. Endocrinology 144, 3742-3748.

Yin, H., Ukena, K., Ubuka, T., and Tsutsui, K. (2005). A novel G protein-coupled receptor for gonadotropin-inhibitory hormone in the Japanese quail
(Coturnix japonica): identification, expression and binding activity. J. Endocrinol. 184, 257-266.

Yoshimura, T., Suzuki, Y., Makino, E., Suzuki, T., Kuroiwa, A., Matsuda, Y., et al. (2000). Molecular analysis of avian circadian clock genes. Brain Res. Mol. Brain Res. 78, 207-215.

Yoshimura, T., Yasuo, S., Suzuki, Y., Makino, E., Yokota, Y., and Ebihara, S. (2001). Identification of the suprachiasmatic nucleus in birds. Am. J. Physiol. Regul. Integr. Comp. Physiol. 280, R1185-R1189.

Yoshimura, T., Yasuo, S., Watanabe, M., Iigo, M., Yamamura, T., Hirunagi, K., et al. (2003). Light-induced hormone conversion of $\mathrm{T} 4$ to $\mathrm{T} 3$ regulates photoperiodic response of gonads in birds. Nature 426, 178-181.

Yuan, H., and Pang, S. F. (1990). [125I]melatonin binding sites in membrane preparations of quail brain: characteristics and diurnal variations. Acta Endocrinol. (Copenh.) 122, 633-639.

Yuan, H., and Pang, S. F. (1991). [125I] Iodomelatonin-binding sites in the pigeon brain: binding characteristics, regional distribution and diurnal variation. J. Endocrinol. 128 475-482.

Yuan, H., and Pang, S. F. (1992). [125I]iodomelatonin binding sites in the chicken brain: diurnal variation and effect of melatonin injection or pinealectomy. Biol. Signals 1, 208-218.

Zann, R. A., Morton, S. R., Jones, K. R., and Burley, N. T. (1995). The timing of breeding by zebra finches in relation to rainfall in central Australia. Emu 95, 208-222.

Conflict of Interest Statement: The authors declare that the research was conducted in the absence of any commercial or financial relationships that could be construed as a potential conflict of interest.

Received: 14 February 2013; paper pending published: 25 February 2013; accepted: 05 March 2013; published online: 25 March 2013.

Citation: Ubuka T, Bentley GE and Tsutsui K (2013) Neuroendocrine regulation of gonadotropin secretion in seasonally breeding birds. Front. Neurosci. 7:38. doi: 10.3389/fnins.2013.00038

This article was submitted to Frontiers in Neuroendocrine Science, a specialty of Frontiers in Neuroscience.

Copyright (c) 2013 Ubuka, Bentley and Tsutsui. This is an open-access article distributed under the terms of the Creative Commons Attribution License, which permits use, distribution and reproduction in other forums, provided the original authors and source are credited and subject to any copyright notices concerning any third-party graphics etc. 